This is the peer reviewed version of the following article: Aziz, Hayfaa Abdul y Sanz Rubio, Enrique y Calvo Sorando, José Pedro y Hilgen, Frederik J. y Krijgsman, Wout (2003) Palaeoenvironmental reconstruction of a middle Miocene alluvial fan to cyclic shallow lacustrine depositional system in the Calatayud Basin (NE Spain). Sedimentology, 50 . pp. 211-236. ISSN 0037-0746, which has been published in final form at https:// doi.org/10.1046/j.1365-3091.2003.00544.x. This article may be used for non-commercial purposes in accordance with Wiley Terms and Conditions for Use of Self-Archived Versions."

\title{
Palaeoenvironmental reconstruction of a middle Miocene alluvial fan to cyclic shallow lacustrine depositional system in the Calatayud Basin (NE Spain)
}

\author{
HAYFAA ABDUL AZIZ*, ENRIQUE SANZ-RUBIOt, JOSE \\ P. CALVOt, FREDIRIK J. HILGEN* and WOUT \\ KRIJGSMAN* \\ *Faculty of Earth Sciences, Utrecht University, Budapestlaan 4, \\ 3584 CD, Utrecht, The Netherlands (E-mail: haziz@geo.uu.nl)
}

\begin{abstract}
tDpto de Geología, Museo Nacional de Ciencias Naturales, CSIC, C/José Gutierrez Abascal 2, 28006 Madrid, Spain

tDpto Petrología y Geoquı'mica, Fac. CC. Geológicas, Universidad Complutense, 28040 Madrid, Spain
\end{abstract}

\section{ABSTRACT}

The middle Miocene sedimentary fill of the Calatayud Basin in north-eastern Spain consists of proximal to distal alluvial fan-floodplain and shallow lacustrine deposits. Four main facies groups characteristic of different sedimentary environments are recognized: (1) proximal and medial alluvial fan facies that comprise clast-supported gravel and subordinate sandstone and mudstone, the latter exhibiting incipient pedogenic features; (2) distal alluvial fan facies, formed mainly of massive mudstone, carbonate-rich palaeosols and local carbonate pond deposits; (3) lake margin facies, which show two distinct lithofacies associations depending on their distribution relative to the alluvial fan system, i.e. front (lithofacies A), comprising massive siliciclastic mudstone and tabular carbonates, or lateral (lithofacies B) showing laminated and/or massive siliciclastic mudstone alternating with tabular and/or laminated carbonate beds; and (4) mudflat-shallow lake facies showing a remarkable cyclical alternation of green-grey and/or red siliciclastic mudstone units and white dolomitic carbonate beds. The cyclic mudflat-shallow lake succession, as exposed in the Orera composite section (OCS), is dominantly composed of small-scale mudstonecarbonate/dolomite cycles. The mudstone intervals of the sedimentary cycles are interpreted as a result of sedimentation from suspension by distal sheet floods, the deposits evolving either under subaerial exposure or water-saturated conditions, depending on their location on the lacustrine mudflat and on climate. The dolomite intervals accumulated during lakelevel highstands with Mg-rich waters becoming increasingly concentrated. Lowstand to highstand lake-level changes indicated by the mudstone/dolomite units of the small-scale cycles reflect a climate control (from dry to wet conditions) on the sedimentation in the area. The spatial distribution of the different lithofacies implies that deposition of the smallscale cycles took place in a low-gradient, shallow lake basin located in an interfan zone. The development of the basin was constrained by gradual alluvial fan aggradation. Additional support for the palaeoenvironmental interpretation is derived from the isotopic compositions of carbonates from the various lithofacies that show a wide range of $\delta^{18} \mathrm{O}$ and $\delta{ }^{13} \mathrm{C}$ values varying from -7.9 to $3.0 \%$ PDB and from -9.2 to $-1.7 \%$ PDB respectively. More negative $\delta^{18} \mathrm{O}$ and $\delta^{13} \mathrm{C}$ values are from carbonate-rich palaeosols and lake- margin carbonates, which extended in front of the alluvial fan systems, whereas more positive values correspond to dolomite beds deposited in the shallow lacustrine environment. The results show a clear trend of $\delta^{18} \mathrm{O}$ enrichment in the carbonates from lake margin to the centre of the shallow lake basin, thereby also demonstrating that the lake evolved under hydrologically closed conditions.

Keywords Calatayud Basin, cyclic sedimentation, dolomite, lacustrine deposits, Miocene, mudstone, palaeoclimate, Spain. 


\section{INTRODUCTION}

Continental deposits have produced some of the finest examples of astronomically controlled cyclicity in sedimentary successions, for example in the Devonian of Scotland (Astin, 1990) and East Greenland (Olsen, 1994), the early Mesozoic Newark Supergroup of eastern North America (Van Houten, 1964; Olsen, 1984, 1986; Gore, 1989; Smoot, 1991), the Eocene Green River Formation of Wyoming (Bradley, 1929; Fischer \& Roberts, 1991; Ripepe et al., 1991) and in the late Neogene Ptolemais Basin of northern Greece (Van Vugt et al., 1998; Steenbrink et al., 1999). Most of these studies are confined to lacustrine successions because they are most sensitive for recording astronomically induced climate change in the continental realm. Recent work by Abdul Aziz et al. (2000, 2001) indicates that the cyclicity in lacustrine to distal alluvial fan-floodplain deposits from the middle Miocene sedimentary fill of the Calatayud Basin, NE Spain, is also astronomically forced. Correlation of the high-resolution magnetostratigraphic record with the geomagnetic polarity time scale (GPTS), corroborated by biostratigraphy, reveals that the cyclic succession ranges in age from 12.8 to $10.7 \mathrm{Ma}$. Spec- tral analyses of proxy records in both the depth and the time domain reveal that the small-scale mudstone-carbonate cycles correspond to the astronomical precession cycle, whereas the large-scale cycles reflect the $400 \mathrm{kyr}$ eccentricity cycle (Abdul Aziz, 2001).

This paper presents the results of detailed sedimentological analysis of the various sedimentary facies deposited in the study area. The geometrical relationships between cyclically bedded deposits and lake margin and alluvial fan sediments provide the basis for a palaeoenvironmental reconstruction of the area during the middle Miocene. Finally, the basic mudstonecarbonate units of the small-scale cycles in the central parts of the lake basin are interpreted in terms of depositional environment, lake level and climate.
GEOLOGICAL SETTING AND STRATIGRAPHIC FRAMEWORK

\section{Tectonic setting}

The Tertiary Calatayud Basin (NE Spain) is an elongate NW-SE-oriented intermontane depression, parallel to the main structures of the Iberian Range (Fig. 1). The Iberian Range constitutes an intraplate fold-and-thrust belt composed of Palaeozoic and Mesozoic rocks, which developed in three stages: (1) rifting and sedimentation during the Mesozoic; (2) crustal thickening and thin-skinned thrusting during the Palaeogene compression; and (3) post-orogenic transtension and crustal thinning from the Neogene to the present (Capote, 1983; Simón, 1990). During the last stage, especially during the Miocene, the Calatayud Basin underwent extensional tectonic deformation, together with a dextral strike-slip component along NW-SE-bounding faults (Hoyos et al., 1996). The geotectonic setting of the Calatayud Basin is complex, being the result of southward-directed compression from the Pyrenees (Simó n, 1990), north- to north-west-directed indentation from the south-eastern corner of the Betic Cordilleras (Doblas et al., 1991) and generalized low-angle extension disrupting the western Mediterranean area (Valencia and Alborán Basins; Doblas \& Oyarzun, 1990).

\section{Stratigraphy}

The basin margin consists mainly of Palaeozoic slate, quartzite and carbonate rocks bounded by NW-SE normal faults (Julivert, 1954; Anadón \& Moissenet, 1996). The sedimentary fill comprises Palaeogene and Neogene sedimentary rocks reaching up to $1200 \mathrm{~m}$ in thickness, as confirmed by borehole data from Marín (1932). The sediment distribution in the basin displays a concentric facies pattern with siliciclastic deposits on the margins passing progressively into carbonates and evaporites towards the central part of the basin, the latter deposits being indicative of a hydrologically closed basin system. The Neogene formations constitute most of the outcrops and 


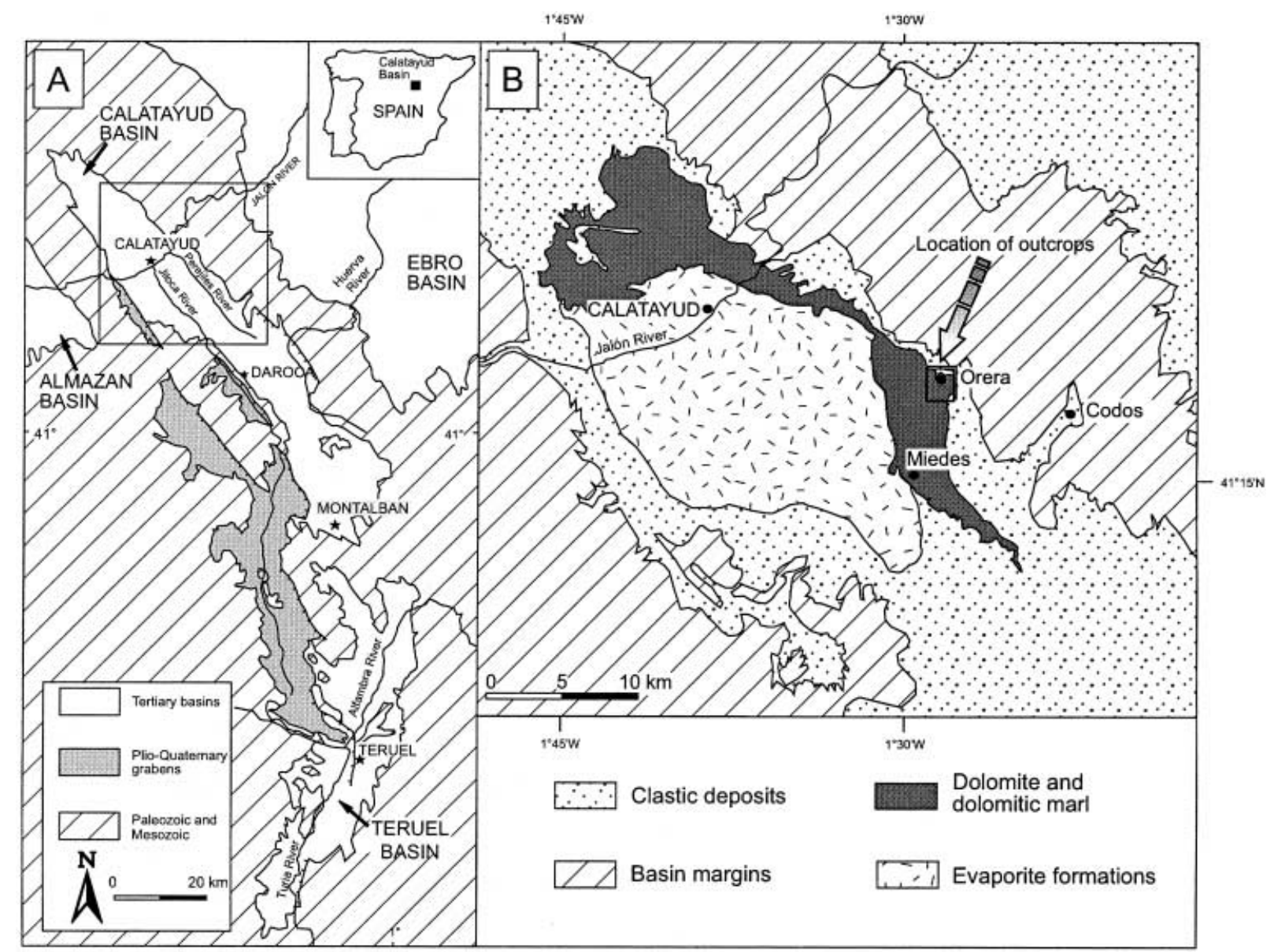

Fig. 1. (A) Location of the study area in the Calatayud Basin; square corresponds to the area of the geological map shown in (B). (B) Schematic geological map with localities mentioned in the text.

are grouped into three main stratigraphic units (Hoyos \& López Martı́nez, 1985; Sanz-Rubio, 1999): the Lower and Intermediate Units, both containing evaporites (Ortí et al., 1994; SanzRubio, 1999), and the Upper Unit mainly composed of terrigenous and freshwater carbonate deposits. Major palaeogeographic changes occurred at the boundary between the Lower and Intermediate Units, which are related to the activity of the NW-SE fault system in the basement, resulting in the development of a palaeokarstic surface on the Lower Unit evaporites in the central part of the basin (Sanz-Rubio, 1999). The palaeokarst surface provides evidence for an episode of subaerial exposure. Where palaeokarstic features are not so evident, the stratigraphic discontinuity is defined by well-marked lithological changes (Sanz-Rubio et al., 2001).

The studied successions belong to the Intermediate Unit and are exposed near the village of Orera, $\approx 15 \mathrm{~km}$ south-east of Calatayud (Fig. 1). In the vicinity of this village, the Neogene strata show a remarkable regularity of bedding, which is particularly clear in the Valdelosterreros area (Fig. 2). Age control for the Neogene deposits is provided by calibration of high-resolution magnetostratigraphy of the cyclically bedded Orera composite section (OCS) to the geomagnetic polarity time scale (GPTS) of Cande \& Kent (1995), yielding an approximate age between 12.8 and 10.7 Ma (late Serravallian to early Tortonian; Krijgsman et al., 1996). This outcome is consistent with biochronological information from micromammal sites near the village of Miedes (Fig. 1), the fauna being characteristic of the Upper Aragonian. Another micromammal site, located in the same hill as section I (Fig. 3), consists of characteristic faunas from the late Aragonian and lower Vallesian (late Serravallian to early Tortonian; Canudo \& Cuenca, 1989).

The carbonate beds of the cyclically bedded succession can be traced laterally towards the village of Orera and towards the north, east and south-east, where they pass progressively into 


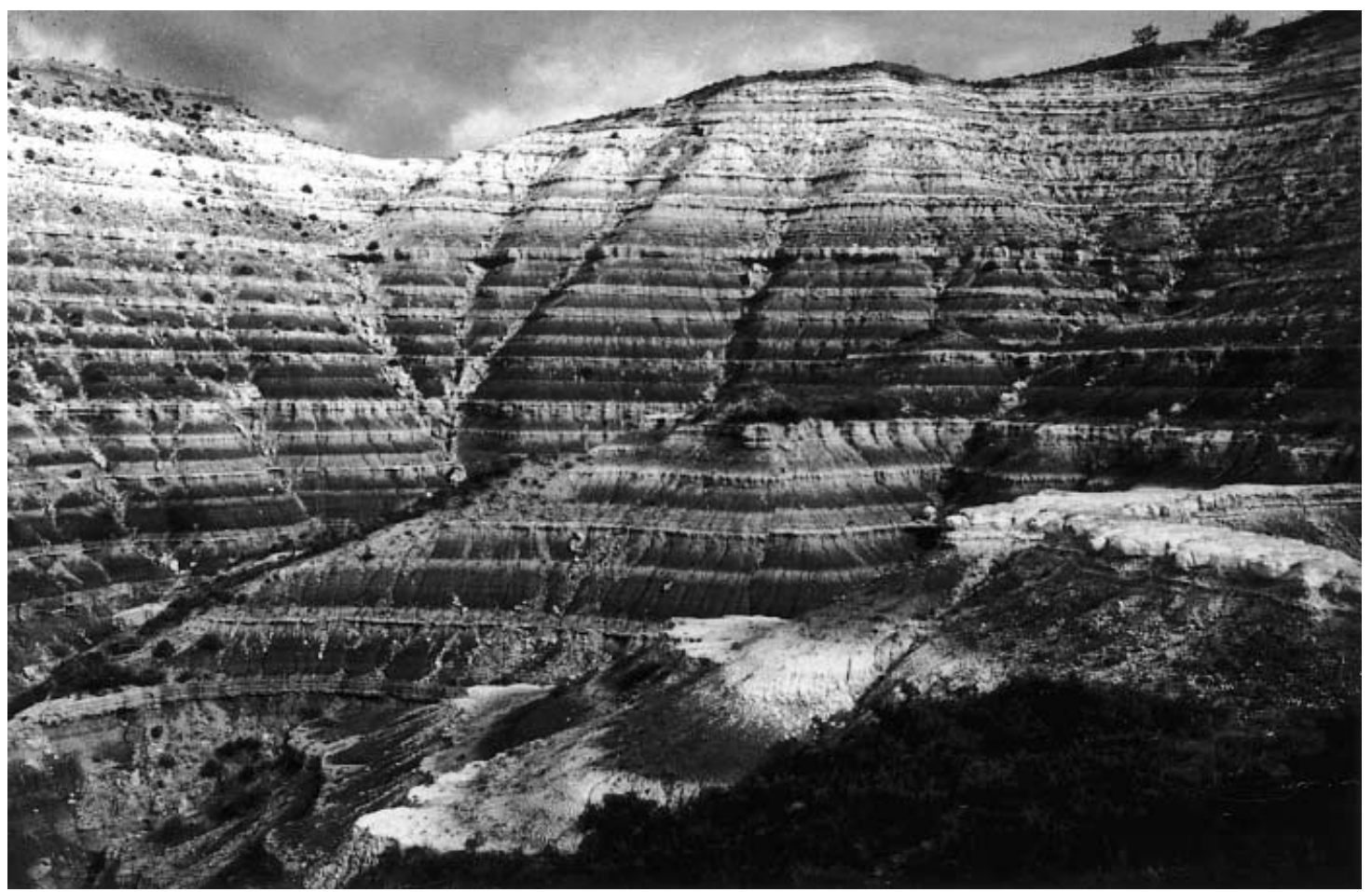

Fig. 2. General view of the Miocene Valdelosterreros section (section IV of Fig. 4) in the Calatayud basin. Height of the exposed succession is $\approx 50 \mathrm{~m}$.

alluvial fan facies (Fig. 3). No outcrops are exposed in the southern part of the study area, although a thick succession of evaporite and mudstone cycles is exposed along the northwestern slope of the Perejiles river valley, which may be the stratigraphic equivalent of the cyclically bedded succession around Orera (Sanz-Rubio et al., 1999).

The lower part of the Orera section correlates with reddish siliciclastic deposits comprising conglomerate, sandstone and mudstone that extend to the north-west and south-east of the area (Fig. 3). In some places, red siliciclastic deposits are capped by carbonate beds, which in turn grade basinward into a succession of mudstone and carbonate deposits. Stratigraphic correlation (Fig. 4) provides evidence of the rapid lateral and vertical facies changes shown by at least the lower part of the middle Miocene sedimentary sections in the area.

\section{FACIES AND DEPOSITIONAL ENVIRONMENTS}

Four main lithofacies groups are recognized in the sedimentary units of the Orera study area. The detailed descriptions and interpretations of these lithofacies are given in Tables $1-3$, and a summary is presented in the following paragraphs.

Proximal and medial alluvial fan facies (Table 1)

The alluvial fan facies, characterized by successions of red siliciclastic deposits more than $100 \mathrm{~m}$ thick, forms a continuous fringe around the entire basin margin (Fig. 1). The width of this alluvial fringe is variable depending on the more or less progradational character of the individual alluvial systems that developed in the area during the Miocene. Near Orera, two main alluvial systems can be recognized: a major NE-SW-trending system located in the Miedes area and a NNESSW-trending alluvial system developed in the proximity of Orera (Figs 1 and 3).

\section{Description}

The alluvial fan deposits extend up to $3 \mathrm{~km}$ from the basin margin. The catchment area is composed of quartzite, slates and metamorphosed carbonate rocks of Early Cambrian age. The proximal facies comprises typically amalgamated and tabular conglomerates that grade laterally into a succession of red to pale brownish conglomerate, sandstone and mudstone beds. 
Fig. 3. Lithofacies map of the Orera area showing the location of the studied sedimentary sections displayed in Fig. 4.

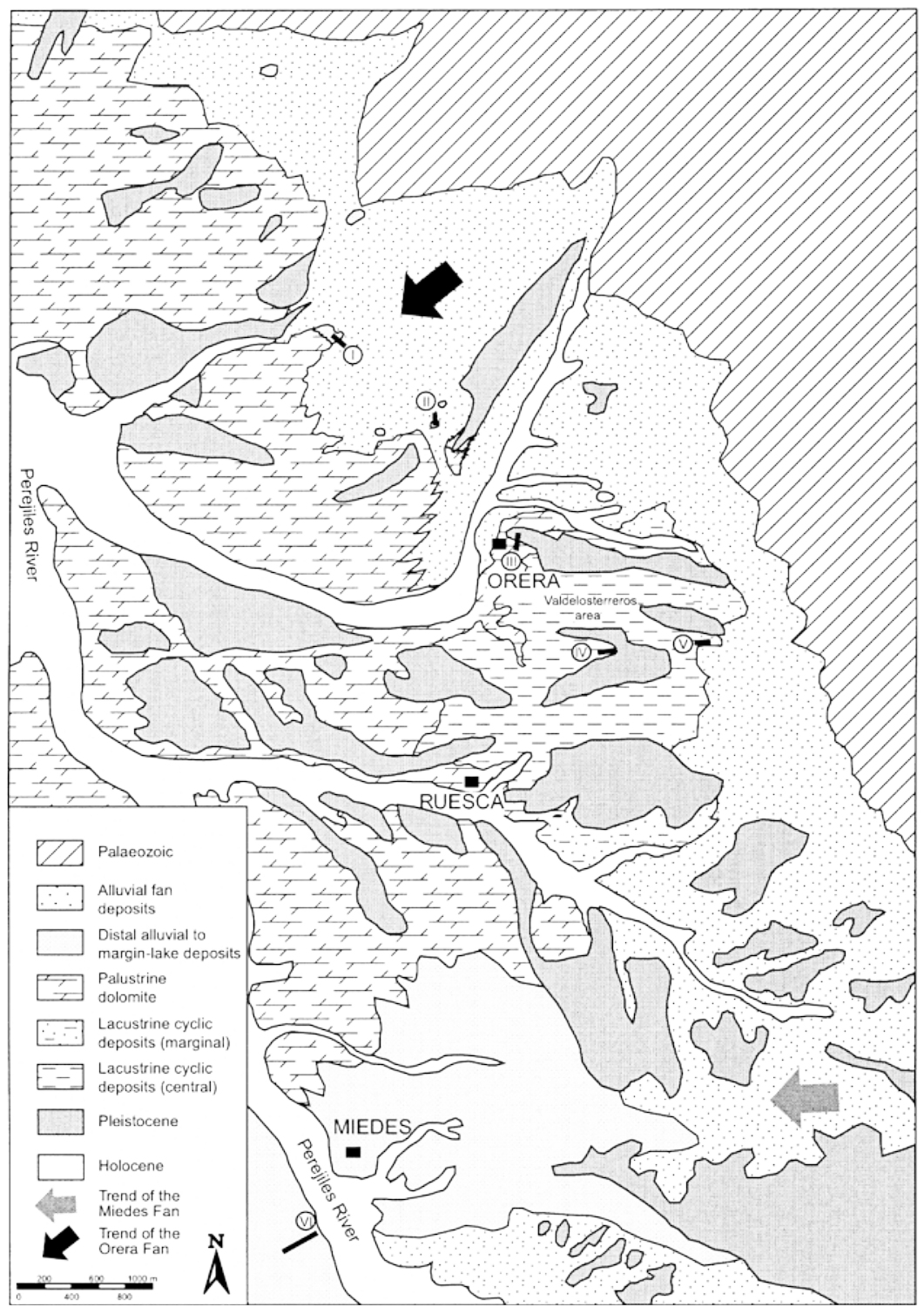

lithofacies (Gm, Gp, Gc; Miall, 1978) is indicative of episodic ephemeral streams. This braided alluvial system expanded radially from the $\mathrm{Pa}$ laeozoic catchment area north-east of Orera, the main axis of the NNE-SSW-trending fan (Fig. 3). Overall, the alluvial fan deposits show a typical downslope-fining trend (Bull, 1997). Some minor coalescing alluvial fans developed eastwards along the margin, but their magnitude is considerably reduced. In medial parts of the fan, deposition took place in ephemeral braided streams (Alonso-Zarza et al., 1993; Bull, 1997) flowing over smooth valley floors. The discontinuous nature of stream deposition is supported by the development of incipient pedogenic features in both sandstone and mudstone deposits (Wright, 1992).
The conglomerate and subordinate sandstone beds of the proximal alluvial fan facies were mainly deposited by stream-dominated flows. The multistorey character of the conglomerate bodies formed of superposed distinct gravel 


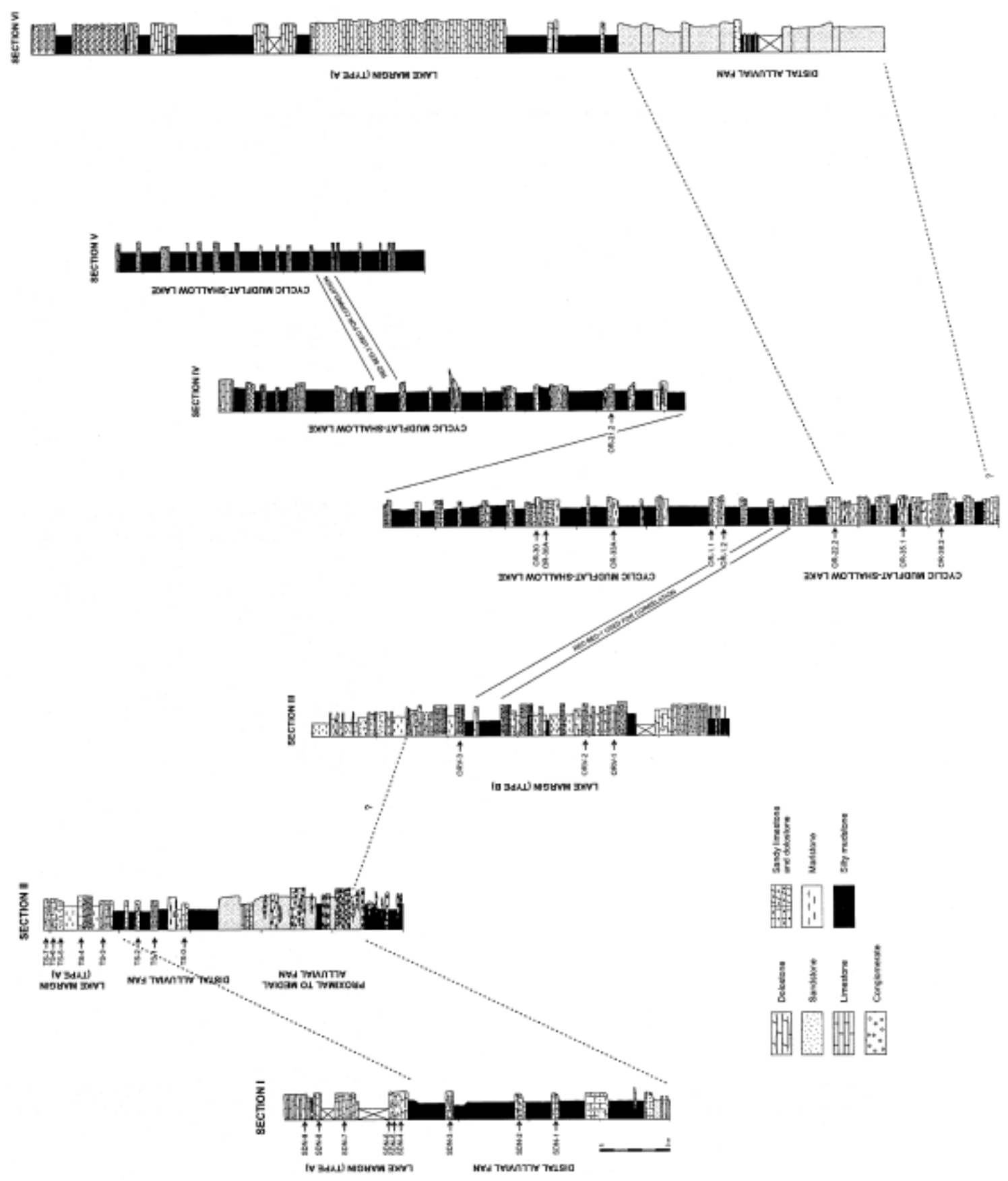


Fig. 4. Lithostratigraphic correlation of sedimentary logs (see Fig. 3 for location of the sections) with sampling levels (see Table 1). Dashed correlation lines indicate approximate (bio)stratigraphic correlations, whereas solid lines indicate characteristic sedimentary pattern correlations (confirmed by magnetostratigraphy; Abdul Aziz et al., 2000).

\section{Distal alluvial fan facies (Table 1)}

\section{Description}

This facies association comprises dominant reddish, massive to vaguely laminated mudstone and subordinate sandstone with intercalated carbonate beds (see lower middle part of section I and upper middle part of section II in Fig. 4; Table 1). The vertical transition from mudstone to carbonate is always gradational. The carbonate beds show a tabular but discontinuous geometry and contain pedogenic features such as vertical root traces, carbonate nodules and platy structures (Esteban \& Klappa, 1983), typical of incipient to relatively mature carbonate-rich palaeosols (stages I to IV calcrete profiles; Gile et al., 1966; Machette, 1985). Less common carbonate features include dolomitic glaebules (Fig. 5A), pseudospherulites (sensu Rossi \& Cañaveras, 1999; Fig. 5B) and vertical and horizontal cracks.

In addition, nodular dolomite beds with tabular geometries and sharp lower contacts occur associated with the massive siliciclastic mudstone. The most typical features of the beds include nodular appearance, fenestral and root-related fabrics and local tepee structures.

\section{Interpretation}

Massive siliciclastic mudstone is interpreted to have formed subaerially in a distal alluvial fan, i.e. sandflat environment. The subordinate sandstone represents mainly episodic sheetflood sedimentation related to dispersed floodwaters, which were discharged onto the distal alluvial areas (Hardie et al., 1978; Hubert \& Hyde, 1982; Demicco \& Gierlowski-Kordesch, 1986). The associated carbonate palaeosols are possibly indicative of periodic stabilization of the clastic input. Overall, the discontinuous lateral geometry and the variable degree of development of palaeosols suggest that ephemeral streams controlled the distribution of both siliciclastic sand and mud deposits and associated soils in these distal fan areas (Wright \& Alonso-Zarza, 1990).
The nodular dolomite beds with palustrine features (sensu Freytet \& Plaziat, 1982; Wright \& Platt, 1995) can be interpreted as deposits that accumulated in shallow ponds of reduced extent that developed on the distal low-gradient areas of the fans (Sanz et al., 1995). The dolomite in these ponds is thought to be a primary precipitate, as deduced from the sedimentological features described in Table 1 . In the ponded areas, primary precipitation of dolomite could have been bacterially induced. The role of bacteria in the precipitation of dolomite in shallow, short-lived lakes has been investigated recently by García del Cura et al. (2001), adding to previous evidence from Vasconcelos \& McKenzie (1997) of microbial mediation in the formation of lacustrine dolomite sediments.

\section{Lake margin facies (Table 2)}

The lake margin facies can be divided into two lithofacies associations depending on their distribution with respect to the alluvial fan facies. The distal parts of the alluvial fans, which coincide with the fans' main axes, comprise sandstones, siltstones and carbonates (lithofacies association A). These deposits can be distinguished from the deposits lateral to the alluvial fans, which consist of cyclic successions of dominant carbonate beds with siliciclastic mudstone (lithofacies association B).

\section{Lake margin lithofacies association $A$ (Table 2)}

Description. Lithofacies association A has been studied in sections I, II and VI (Figs 3 and 4). The association comprises both terrigenous, mainly silt-clay deposits, and carbonate beds, the latter consisting of palustrine and shallow lake carbonates.

The terrigenous sediments are mainly formed of greyish pink massive to light green, vaguely laminated mudstone. Massive siliciclastic mudstone exhibits widely developed mottling and abundant root traces. Laminated siliciclastic mudstone contains abundant plant remains and locally includes calcareous concretions and rhizotubules.

The carbonate, mainly dolomite, occurs as tabular beds in which several subfacies are recognised: (1) massive nodular dolomite; (2) extensive root-bioturbated dolomite beds (see Fig. 5C); (3) horizontally cracked dolomite beds; and (4) sandy to silty, laminated carbonate (see Table 2 for details). 


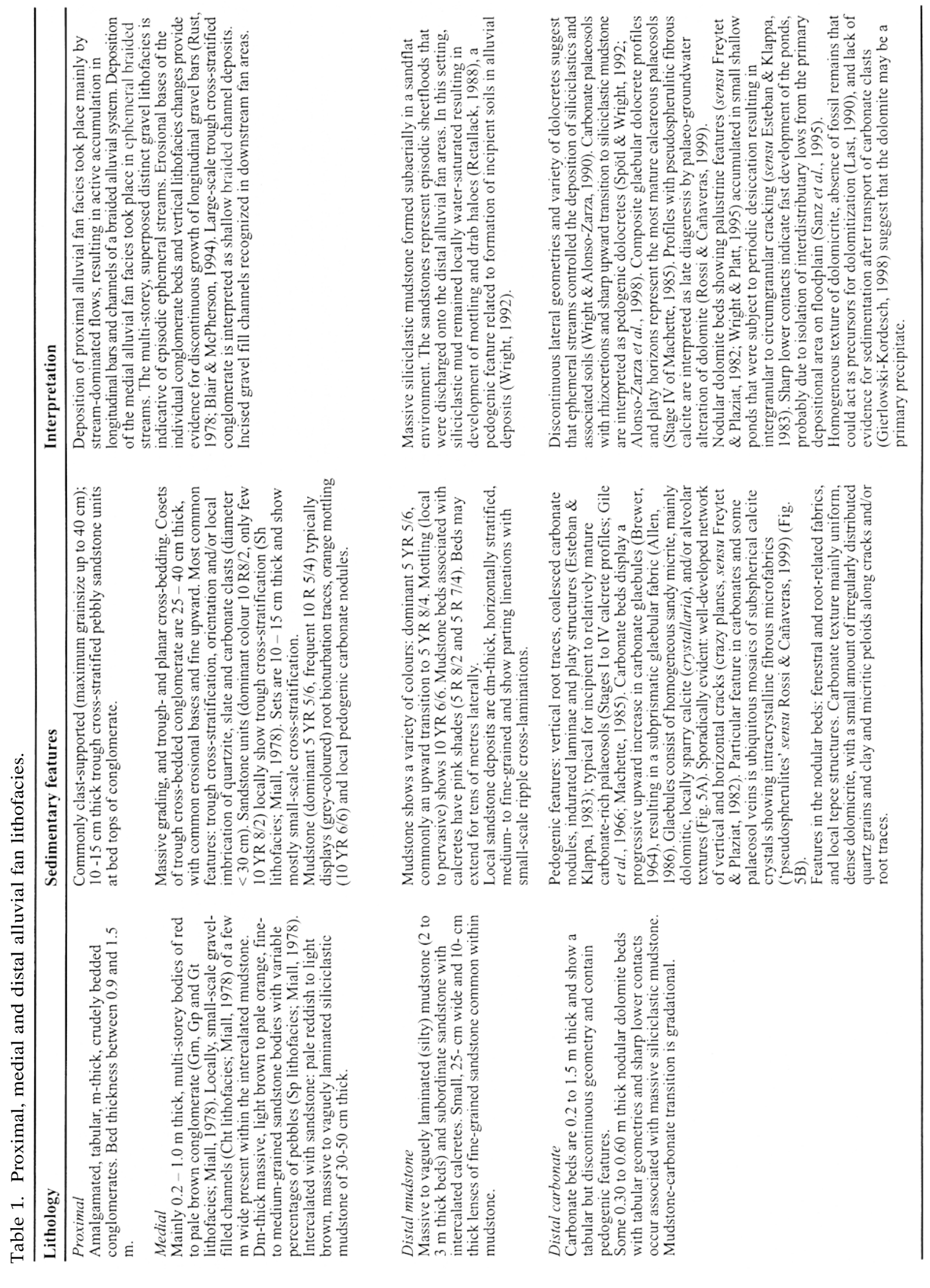




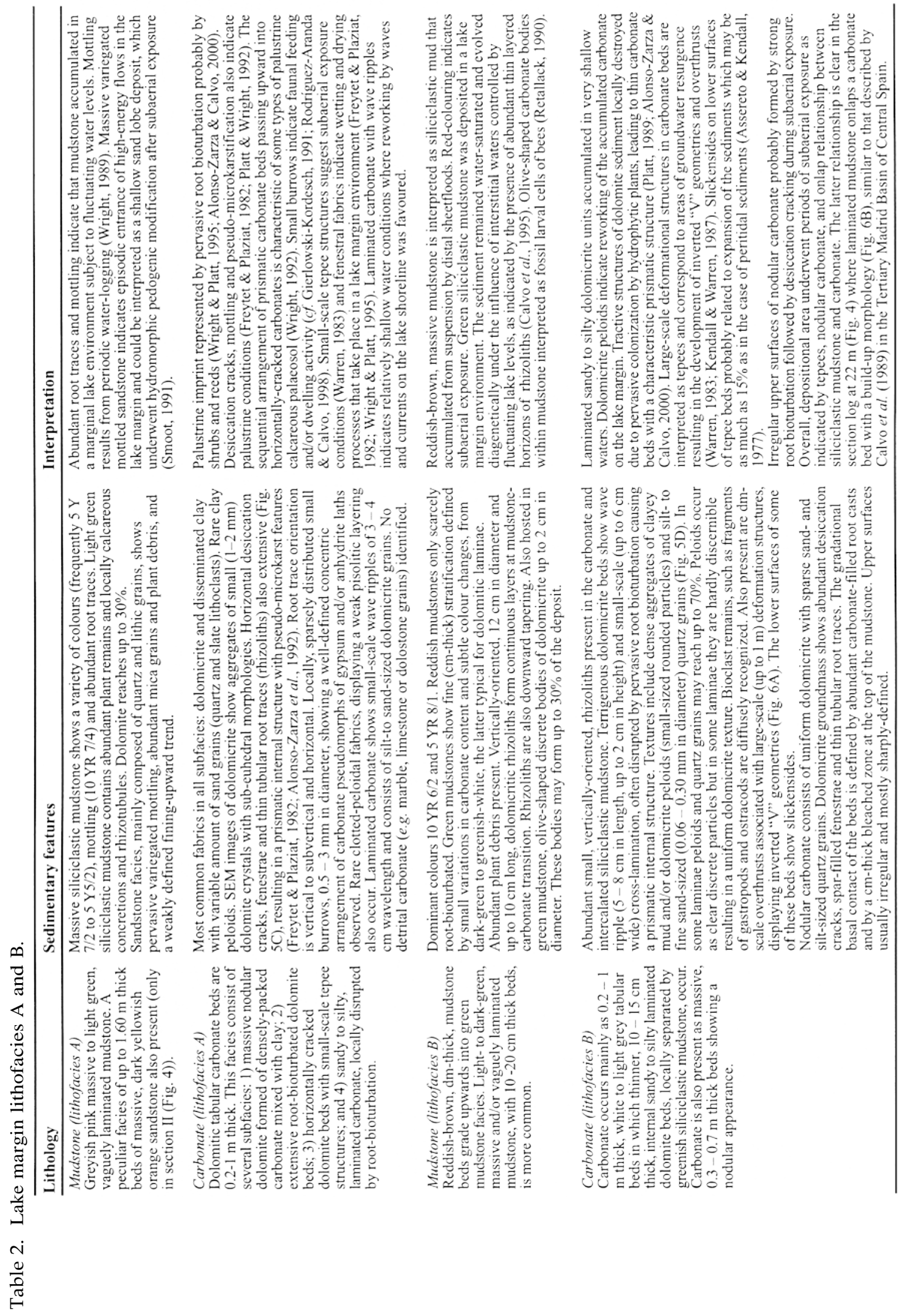




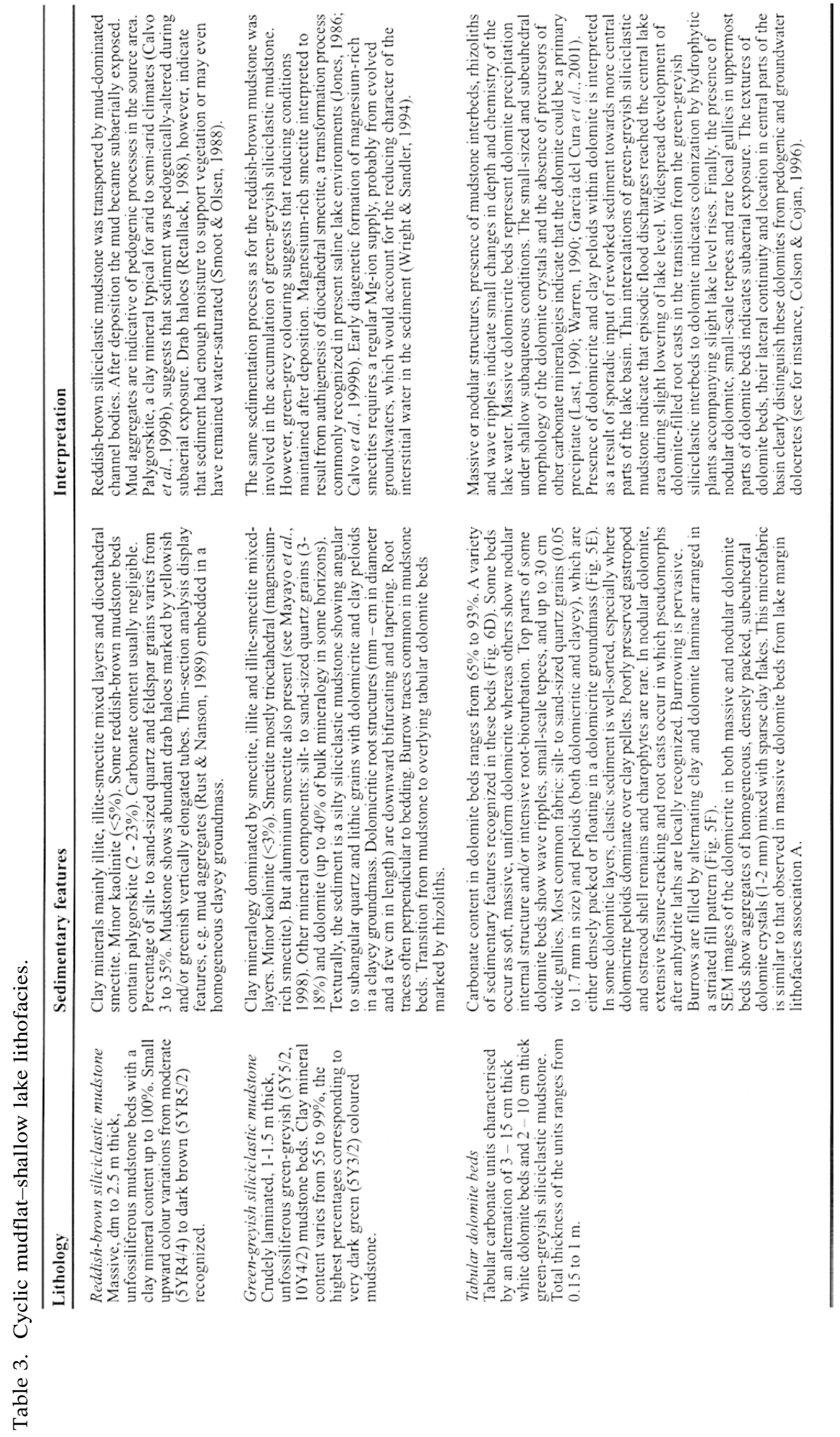



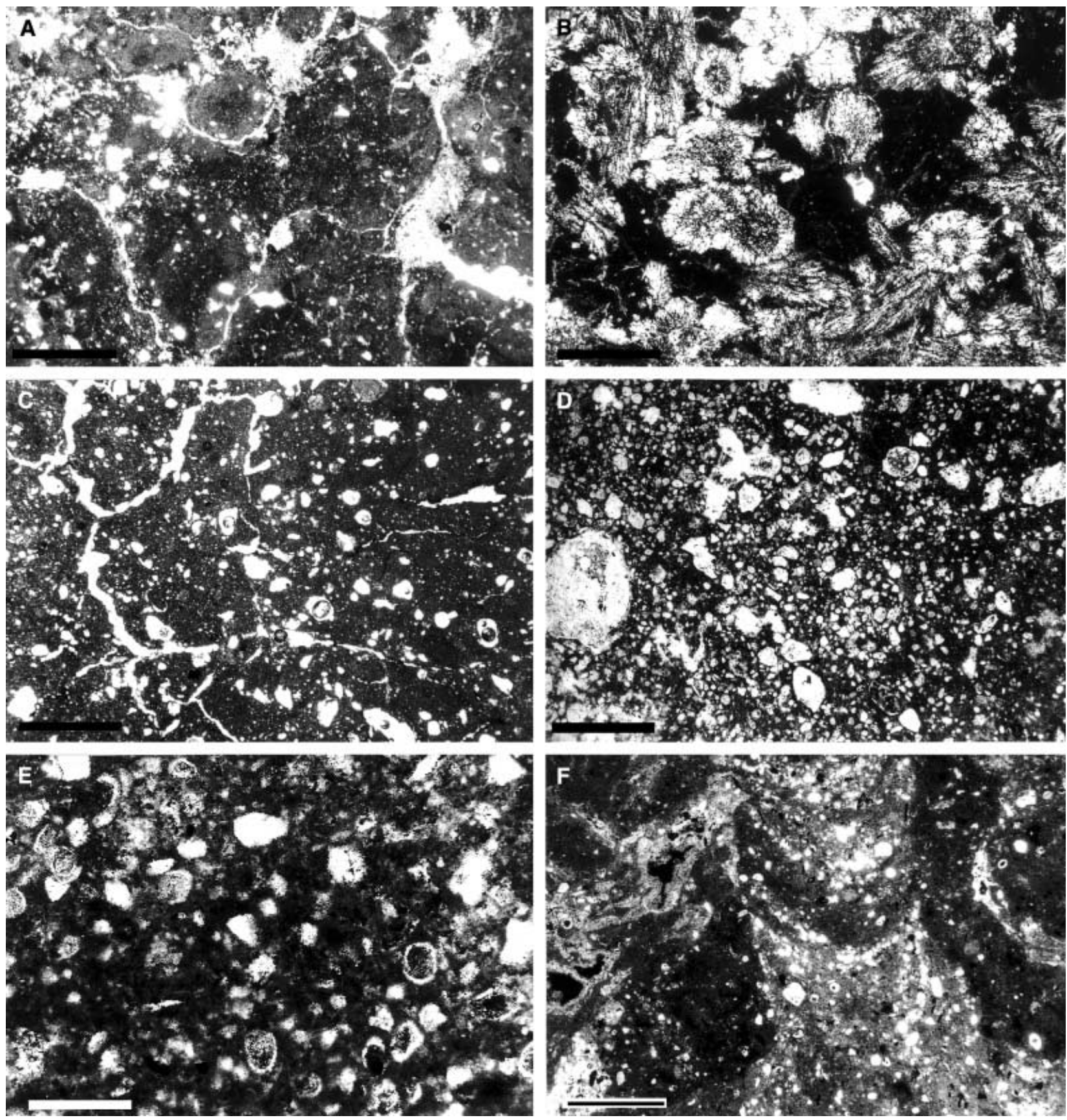

Fig. 5. Photomicrographs (polarized light) of selected carbonate facies from the Miocene of the Orera-Valdelosterreros area. (A) Non-homogeneous fabric of a calcareous palaeosol (dolocrete) developed in distal alluvial facies; the fabric consists of fine-grained sandy micrite with elongate holes (roots), partially filled by calcite spar, and circumgranular desiccation cracks. (B) Widely developed pseudospherulitic fibrous calcite (pseudospherulites; sensu Rossi \& Cañaveras, 1999) in dolocrete of the distal alluvial fan facies. (C) Irregular horizontal desiccation cracks and vertically oriented, thin tubular root cavities in sandy dolomicrite (lake margin lithofacies association A); note the fenestral appearance of this fabric. (D) Uniform dolomicrite (dark ground) containing abundant peloids and quartz grains; individual peloids range from 0.1 to $0.5 \mathrm{~mm}$ in diameter (lake margin lithofacies association B). (E) Concentric peloids and quartz sand grains in dolomicrite forming carbonate beds of the cyclic mudflat-shallow lake facies. (F) Detail of a burrow structure developed in a shallow carbonate lacustrine environment; note the striated fill pattern characterized by alternating laminae of dolomicrite and coarser grained sediment comprising quartz sand grains and peloids. Scale bar in all photomicrographs is $1 \mathrm{~mm}$. 
Interpretation. Lithofacies association A records deposition in a marginal lake environment where water level fluctuated periodically (Freytet \& Plaziat, 1982; Platt \& Wright, 1992; Wright \& Platt, 1995). The variable colours and abundant mottling of the siliciclastic mudstone facies indicate that the mudstone accumulated, probably by sedimentation from suspension bedload, in a marginal lake area that was subjected to periodic wetting and drying processes related to fluctuating water level (Gierlowski-Kordesch \& Rust, 1994; Wright \& Sandler, 1994).

The variety of subfacies recognized within the carbonate lithofacies indicates that different subenvironments are associated with the lake margin. Massive mud-grade nodular carbonate is interpreted to result from primary precipitation of dolomite (García del Cura et al., 2001), followed by periodic desiccation, probably accompanied by root penetration, leading to extensive cracking of the sediment (Platt, 1989; Calvo et al., 1995). Carbonates showing tepee structures and fenestral fabrics are indicative of subaerial exposure and wetting/drying processes that occur along the lake margin (Freytet \& Plaziat, 1982; Wright \& Platt, 1995). The laminated carbonate represents relatively shallow lake deposits that accumulated basinward at the most distal parts of the alluvial fans.

\section{Lake margin lithofacies association $B$} (Table 2)

Description. This facies association has been recognized near the village of Orera (section III in Fig. 4), where massive and/or laminated siliciclastic mudstone and marlstone alternates with tabular and/or laminated silty carbonate beds forming a well-defined cyclic succession. East of Orera, the succession can be correlated bed-tobed with the remarkably cyclically bedded succession of Valdelosterreros (section IV in Fig. 4; Abdul Aziz et al., 2000).

Two siliciclastic mudstone facies are distinguished: reddish-brown massive mudstone and light to dark green massive and/or vaguely laminated mudstone. The reddish-brown type mostly grades upwards into the green mudstone facies and exhibits sparse root traces. The more common greenish mudstone type shows fine stratification, abundant plant debris and rhizoliths, the latter developed at the transition between the mudstone and the overlying carbonate.
Carbonate occurs as white to light grey tabular dolomite beds or as massive beds showing a nodular appearance. The tabular beds show sedimentary features similar to the laminated carbonate beds observed within the lake margin lithofacies association A; however, more distinctive features include clayey mud aggregates and dolomicrite peloids (Fig. 5D). In addition, largescale deformation structures showing inverted ' $\mathrm{V}$ ' geometries are also present (Fig. 6A). The massive dolomite beds have a gradational basal contact with silty laminated carbonate, whereas the upper surfaces are usually irregular and mostly sharply defined.

Interpretation. The alternating mudstone and carbonate deposits of this lithofacies association were deposited in a low-gradient lake-margin environment. Similar facies have been described from both ancient and recent sedimentary settings elsewhere (Turnbridge, 1984; Calvo et al., 1989; Talbot et al., 1994). The reddish-brown, massive mudstone is interpreted as siliciclastic mud that accumulated from suspension by distal sheetfloods. After sedimentation, the mud remained subaerially exposed, thus evolving under oxidizing conditions and subject to local pedoturbation. Accordingly, a similar sedimentation pattern is postulated for the accumulation of the green siliciclastic mudstone deposits, although in this case the sediment remained water saturated, i.e. under reducing conditions, as suggested by the green-grey colouring and the preserved plant debris (Wright \& Sandler, 1994; Reinhardt \& Ricken, 2000).

The laminated sandy to silty dolomicrite units accumulated in very shallow waters subject to periodic wave and current activity. The largescale deformational structures in the carbonate beds are interpreted as tepee-like structures and correspond to areas of groundwater resurgence that affected exposed sediments along the edge of a lake (Warren, 1983; Kendall \& Warren, 1987).

Besides the shallow character, several other features (see Table 2 and Fig. 6B) provide evidence that the depositional area became episodically subaerially exposed. Based on the sedimentary features observed in this lithofacies association and its stratigraphic relationships with other facies, a low-gradient, low-energy, lake-margin environment can be inferred (Wright, 1990). 

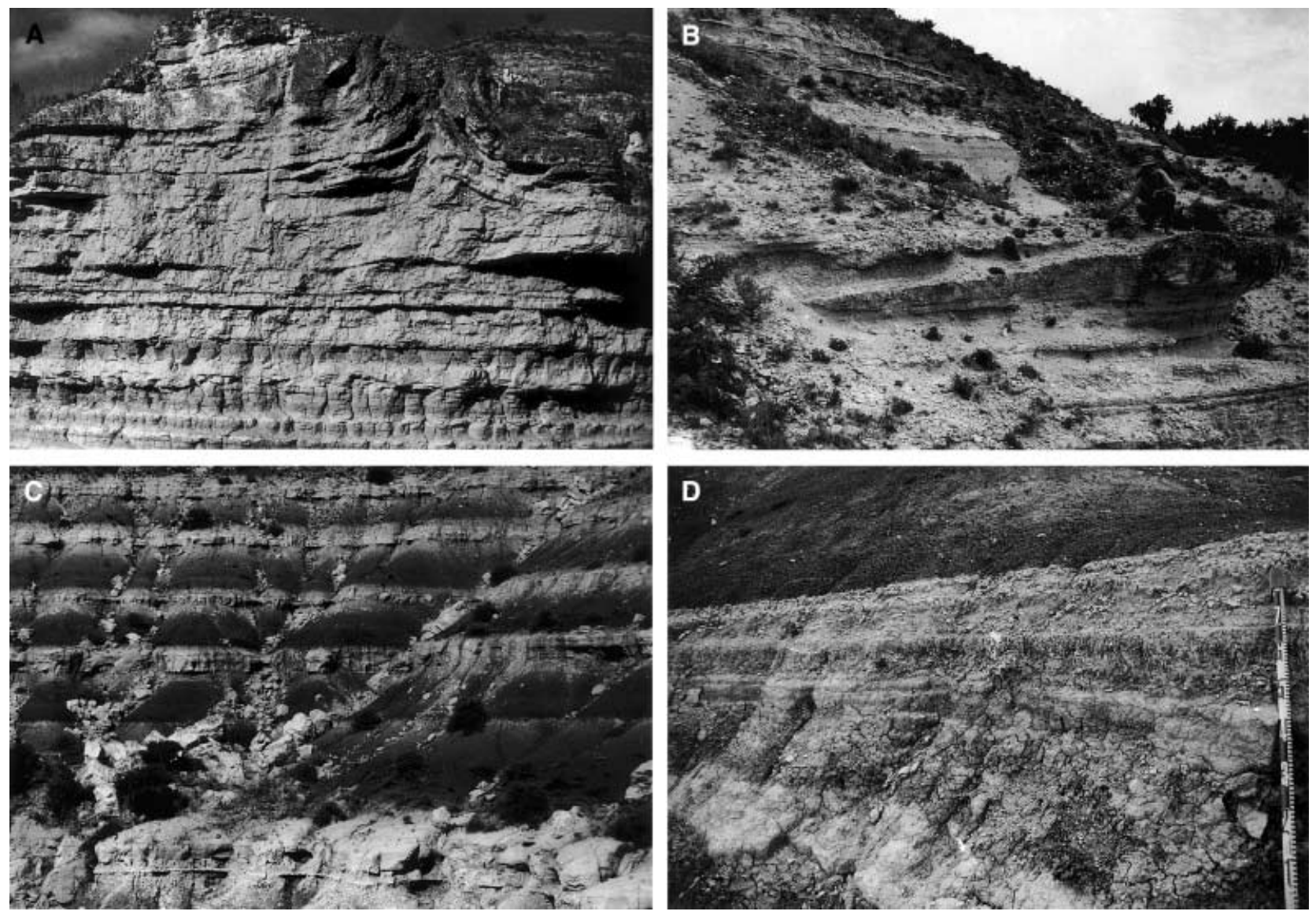

Fig. 6. (A) Large-scale deformation structures interpreted as tepees developed in carbonate beds of the lake margin lithofacies association B. Height of the outcrop is $4 \mathrm{~m}$. (B) Carbonate bed showing an irregular, convex-up, moundlike morphology (thickness is $\approx 1 \mathrm{~m}$; lake margin lithofacies association $\mathrm{B}$ ). The depression to the left of the car- bonate mound is filled with mudstone that is covered by a carbonate bed onlapping the mound. (C) Outcrop view of basic smallscale cycles formed of mudstone (dark) and carbonate (white) beds (Valdelosterreros area; section IV of Fig. 4). Thickness of the sedimentary cycles measured in the photograph is $1.7 \mathrm{~m}$. (D) Close-up view of a carbonate unit of a small-scale sedimentary cycle from the cyclic mudflat-shallow lake facies (scale at right, about $0.8 \mathrm{~m}$ ). A variety of carbonate deposits occur interbedded with thin green-greyish mudstone: massive dolomite is present at the base of the carbonate unit, followed upwards by thin bedded dolomite; the upper part of the carbonate unit is formed of a densely packed array of rhizoliths capped by nodular dolomite.

\section{Cyclic mudflat-shallow lake facies (Table 3)}

\section{Description}

This lithofacies is remarkably well exposed in the Valdelosterreros area (section IV of Fig. 4), east of the village of Orera (Figs 2 and 3). In this location, which was proposed as a cultural and geological heritage site (Calvo et al., 1999a), the studied stratigraphic succession reaches up to $78 \mathrm{~m}$ in thickness and comprises 35 basic small-scale cycles (Abdul Aziz et al., 2000). The cyclicity is defined by two components: a mudstone unit formed mainly of massive, usually strongly rootpenetrated green-greyish siliciclastic mudstone, and a carbonate unit composed of white dolomite beds (Fig. 6C). Reddish-brown siliciclastic mudstone is only rarely identified in the lower unit of the cycles. It either directly overlies a dolomite bed or grades upwards from greengreyish siliciclastic mudstone.

The reddish-brown mudstone facies comprises massive unfossiliferous siliciclastic mudstone with a high clay mineral content. Characteristic features include abundant drab haloes and mud aggregates (Rust \& Nanson, 1989). The greengreyish mudstone facies is strongly root bioturbated and comprises laminated, unfossiliferous green-greyish siliciclastic mudstone with a variable clay mineral content. The transition between the mudstone and the overlying tabular dolomite beds is commonly marked by rhizoliths that penetrate a few centimetres downwards into the mudstone. 
The tabular dolomite lithofacies consists of an alternation of white dolomite beds and greengreyish siliciclastic mudstone beds together forming tabular carbonate-dominated units at the top of the cycles (Fig. 6D). The dolomite beds are formed of soft, massive, uniform dolomicrite commonly composed of quartz and peloid grains (Fig. 5E) or consist of a nodular internal structure and/or display a laterally densely packed array of dolomicritic rhizoliths (Fig. 5F).

North-east of the Valdelosterreros area, closer to the basin margin, the cyclic sedimentary succession is also formed of mudstone-carbonate cycles (section V of Fig. 4). However, the mudstone beds are mainly reddish-brown and show a higher content of silt-sized grains. Intensive root bioturbation is also common in this mudstone. Carbonate beds, forming the upper part of the sedimentary cycles, display tabular geometries but are thinner than in the Valdelosterreros section.

\section{Interpretation}

The remarkable lateral continuity (at least $600 \mathrm{~m}$ ) of the siliciclastic mudstone and carbonate beds over the Valdelosterreros area indicates that deposition took place in a low-gradient, shallow lake basin. The upward persistence of the cyclic sedimentary pattern shown by these facies suggests a unique balance between sedimentation and subsidence over a considerable time interval.

The reddish-brown mudstone resulted from episodic flood discharge through mud-dominated channel bodies into the basin, but remained subaerially exposed after deposition. The presence of palygorskite strongly suggests that the sediment underwent pedogenic alterations during subaerial exposure, the clay mineral being typical of arid to semi-arid climate conditions (Calvo et al., 1999b).

Accumulation of green-greyish siliciclastic mudstone resulted from episodic flood discharges leading to rapid decantation of clay particles from highly concentrated suspension load (Vandervoort, 1997). The accumulation process is similar to that for the reddish-brown muds, but the green-grey colouring suggests that reducing conditions prevailed after deposition.

The textural features shown by the dolomite units (Table 4) indicate that massive dolomicrite beds represent precipitation of dolomite under shallow subaqueous conditions. The features also support the notion that the dolomite is a primary precipitate (Last, 1990; Warren, 1990; García del Cura et al., 2001), as precursors of other carbonate mineralogies have rarely been recognized. The formation of dolomite resulted from precipitation after progressive concentration of Mg-enriched lake waters, a process that was probably driven by increasing evaporation of ponded water in the basin. These hydrochemical conditions could be similar to those invoked for the formation of the Coorong dolomites (Von der Borch \& Lock, 1979) and other lacustrine primary dolomites around the world (Last, 1990). Although no clear petrographic evidence for a bacterial origin of the dolomites from Orera has been found (García del Cura et al., 2001), a contribution to their formation from microorganism communities cannot be excluded (Vasconcelos \& McKenzie, 1997; Wright, 1999).

Table 4. Oxygen and carbon isotope composition of selected carbonate samples from the Orera-Valdelosterreos area.

\begin{tabular}{|c|c|c|c|c|c|c|c|c|c|}
\hline \multirow[b]{2}{*}{ Sample } & \multirow[b]{2}{*}{ Facies } & \multicolumn{4}{|c|}{ Mineralogy percentage } & \multicolumn{2}{|c|}{ Calcite } & \multicolumn{2}{|c|}{ Dolomite } \\
\hline & & Calcite & Dolomite & Clay Min. & $\mathrm{Q}+$ Feld & $\delta^{18} \mathrm{O}$ & $\delta^{13} \mathrm{C}$ & $\delta^{18} \mathrm{O}$ & $\delta^{13} \mathrm{C}$ \\
\hline TS-00 & $\begin{array}{l}\text { Carbonate palaeosol } \\
\text { (Distal alluvial fan) }\end{array}$ & 5 & 79 & 6 & 10 & $-0 \cdot 7$ & $-7 \cdot 4$ & $0 \cdot 6$ & $-7 \cdot 5$ \\
\hline TS-01 & $\begin{array}{l}\text { Carbonate palaeosol } \\
\text { (Distal alluvial fan) }\end{array}$ & 71 & 14 & 10 & 5 & $-7 \cdot 9$ & $-9 \cdot 2$ & $-3 \cdot 0$ & $-7 \cdot 1$ \\
\hline TS-02 & $\begin{array}{l}\text { Rooted carbonate } \\
\text { (Distal alluvial fan) }\end{array}$ & 31 & 47 & 7 & 15 & $-4 \cdot 5$ & $-7 \cdot 6$ & $-2 \cdot 2$ & $-5 \cdot 9$ \\
\hline TS-03 & $\begin{array}{l}\text { Carbonate palaeosol } \\
\text { (Lake margin A) }\end{array}$ & 21 & 49 & 2 & 28 & $-2 \cdot 9$ & $-5 \cdot 8$ & $0 \cdot 8$ & $-3 \cdot 3$ \\
\hline TS-04 & $\begin{array}{l}\text { Carbonate palaeosol } \\
\text { (Lake margin A) }\end{array}$ & 52 & 24 & 3 & 21 & $-3 \cdot 3$ & $-7 \cdot 0$ & $1 \cdot 4$ & $-4 \cdot 8$ \\
\hline TS-05 & $\begin{array}{l}\text { Rooted carbonate } \\
\text { (Lake margin A) }\end{array}$ & 9 & 88 & 3 & - & $-2 \cdot 0$ & $-6 \cdot 3$ & $-2 \cdot 1$ & $-6 \cdot 0$ \\
\hline TS-06 & Fenestral carbonate & 8 & 89 & 3 & - & $-2 \cdot 1$ & $-6 \cdot 1$ & $-2 \cdot 3$ & $-5 \cdot 8$ \\
\hline
\end{tabular}


Table 4. Continued.

\begin{tabular}{|c|c|c|c|c|c|c|c|c|c|}
\hline \multirow[b]{2}{*}{ Sample } & \multirow[b]{2}{*}{ Facies } & \multicolumn{4}{|c|}{ Mineralogy percentage } & \multicolumn{2}{|c|}{ Calcite } & \multicolumn{2}{|c|}{ Dolomite } \\
\hline & & Calcite & Dolomite & Clay Min. & $\mathrm{Q}+$ Feld & $\delta^{18} \mathrm{O}$ & $\delta^{13} \mathrm{C}$ & $\delta^{18} \mathrm{O}$ & $\delta^{13} \mathrm{C}$ \\
\hline & (Lake margin A) & & & & & & & & \\
\hline TS-07 & $\begin{array}{l}\text { Rooted carbonate } \\
\text { (Lake margin A) }\end{array}$ & 7 & 87 & 5 & 1 & $-2 \cdot 2$ & $-5 \cdot 4$ & $-2 \cdot 3$ & $-5 \cdot 3$ \\
\hline SDN-01 & $\begin{array}{l}\text { Carbonate palaeosol } \\
\text { (Distal alluvial fan) }\end{array}$ & - & 75 & 14 & 11 & & & $-4 \cdot 2$ & $-7 \cdot 3$ \\
\hline SDN-02 & $\begin{array}{l}\text { Carbonate palaeosol } \\
\text { (Distal alluvial fan) }\end{array}$ & 3 & 68 & 15 & 14 & & & $-3 \cdot 5$ & $-6 \cdot 6$ \\
\hline SDN-03 & $\begin{array}{l}\text { Sandy carbonate with tepees } \\
\text { (Lake margin A) }\end{array}$ & - & 76 & 3 & 21 & & & $-3 \cdot 2$ & $-6 \cdot 8$ \\
\hline SDN-04 & $\begin{array}{l}\text { Massive carbonate } \\
\text { (Lake margin A) }\end{array}$ & 4 & 82 & 7 & 7 & & & $0 \cdot 3$ & $-6 \cdot 9$ \\
\hline SDN-05 & $\begin{array}{l}\text { Massive carbonate } \\
\text { (Lake margin A) }\end{array}$ & - & 91 & 6 & 3 & & & $-1 \cdot 8$ & $-6 \cdot 6$ \\
\hline SDN-06 & $\begin{array}{l}\text { Massive carbonate } \\
\text { (Lake margin A) }\end{array}$ & 2 & 81 & 11 & 6 & & & $3 \cdot 0$ & $-7 \cdot 3$ \\
\hline SDN-07 & $\begin{array}{l}\text { Sandy-rooted carbonate } \\
\text { (Lake margin A) }\end{array}$ & - & 80 & 5 & 15 & & & $2 \cdot 5$ & $-5 \cdot 4$ \\
\hline SDN-08 & $\begin{array}{l}\text { Nodular laminated carbonate } \\
\text { (Lake margin A) }\end{array}$ & - & 88 & 5 & 7 & & & $-1 \cdot 5$ & $-4 \cdot 7$ \\
\hline SDN-09 & $\begin{array}{l}\text { Laminated-rooted carbonate } \\
\text { (Lake margin A) }\end{array}$ & - & 86 & 13 & 1 & & & $1 \cdot 8$ & $-6 \cdot 0$ \\
\hline ORV-1 & $\begin{array}{l}\text { Silty carbonate } \\
\text { (Lake margin B) }\end{array}$ & 1 & 88 & 10 & 1 & & & $-1 \cdot 3$ & $-5 \cdot 8$ \\
\hline ORV-2 & $\begin{array}{l}\text { Laminated-rooted silty carbonate } \\
\text { (Lake Margin B) }\end{array}$ & - & 79 & 9 & 12 & & & $-1 \cdot 0$ & $-3 \cdot 9$ \\
\hline ORV-3 & $\begin{array}{l}\text { Laminated and rooted carbonate } \\
\text { (Lake Margin B) }\end{array}$ & - & 84 & 8 & 8 & & & $0 \cdot 0$ & $-2 \cdot 5$ \\
\hline OR-1Æ1 & $\begin{array}{l}\text { Brecciated-rooted carbonate } \\
\text { (Shallow lake) }\end{array}$ & - & 90 & 9 & 2 & & & $2 \cdot 8$ & $-2 \cdot 0$ \\
\hline OR-1Æ2 & $\begin{array}{l}\text { Silty-rooted tabular carbonate } \\
\text { (Shallow lake) }\end{array}$ & 3 & 77 & 23 & - & & & $2 \cdot 9$ & $-2 \cdot 4$ \\
\hline OR-22Æ2 & $\begin{array}{l}\text { Silty massive tabular carbonate } \\
\text { (Shallow lake) }\end{array}$ & - & 70 & 12 & 18 & & & $2 \cdot 5$ & $-2 \cdot 1$ \\
\hline OR-35Æ1 & $\begin{array}{l}\text { Mound-shaped rooted carbonate } \\
\text { (Lake Margin B) }\end{array}$ & - & 83 & 16 & 1 & & & $-0 \cdot 6$ & $-4 \cdot 5$ \\
\hline OR-38Æ2 & $\begin{array}{l}\text { Tabular rooted carbonate } \\
\text { (Shallow lake) }\end{array}$ & - & 83 & 17 & - & & & $1 \cdot 8$ & $-4 \cdot 5$ \\
\hline OR-21Æ2 & $\begin{array}{l}\text { Tabular massive carbonate } \\
\text { (Shallow lake) }\end{array}$ & - & 77 & 12 & 11 & & & $2 \cdot 5$ & $-2 \cdot 2$ \\
\hline OR-30 & $\begin{array}{l}\text { Tabular rooted carbonate } \\
\text { (Shallow lake) }\end{array}$ & - & 87 & 9 & 4 & & & $1 \cdot 6$ & $-3 \cdot 5$ \\
\hline OR-30A & $\begin{array}{l}\text { Tabular rooted carbonate } \\
\text { (Shallow lake) }\end{array}$ & - & 73 & 23 & - & & & $2 \cdot 2$ & $-3 \cdot 0$ \\
\hline OR-33A & $\begin{array}{l}\text { Tabular rooted carbonate } \\
\text { (Shallow lake) }\end{array}$ & - & 91 & 7 & 1 & & & 1.9 & $-1 \cdot 7$ \\
\hline
\end{tabular}

Mineralogy of the samples is based on semi-quantitative analysis of XRD measurements. The sampled levels and their stratigraphic positions are shown in the lithostratigraphic logs of Fig. 4.

\section{STABLE ISOTOPES}

To provide an independent check on the interpretation of the different lithofacies associations, stable isotope analyses were carried out on 29 carbonate samples, representative of the various lithofacies associations that were distinguished by sedimentological analysis (Table 4 ). Detailed petrography and X-ray diffraction (XRD) measurements indicate that dolomite is the main carbonate mineral present in most of the samples. The primary precipitate origin of the dolomites 
(see discussion above) allows the isotopic signals to be used for palaeoenvironmental interpretations (Talbot \& Kelts, 1990). In some cases, especially in carbonate palaeosols, calcite is present as a major mineral, whereas it is subordinate to dolomite in some deposits of lakemargin facies association A (Table 4).

The stable isotope analyses were performed in the Laboratory of Analytic Geochemistry of the Faculty of Earth Sciences at Utrecht University (The Netherlands). All samples were prepared and analysed in duplicate. The analytical preci- sion is generally $\pm 0.15 \%$ o for oxygen and \pm 0.10 \& for carbon. The samples were first washed with distilled water to eliminate the soluble salts and then dried. All samples were treated with $100 \% \mathrm{H}_{3} \mathrm{PO}_{4}$ at $25{ }^{\circ} \mathrm{C}$. For mixed carbonate samples, both calcite and dolomite were analysed if the lesser mineral constituted at least $10 \%$ of the total carbonate; otherwise, only the dominant mineral was analysed. The carbon dioxide evolved in the first hour was attributed to calcite; the gas evolved between $24 \mathrm{~h}$ and $40 \mathrm{~h}$ was attributed to dolomite. The resulting $\mathrm{CO}_{2}$ gas was analysed on a VG-SIRA 24 mass spectrometer. The results are expressed by the conventional d-notation relative to the PDB standard. For the dolomites, the $\delta^{18} \mathrm{O}$ values were corrected by $-0.8 \%$ for the fractionation effect during phosphoric acid reac- tion (Sharma \& Clayton, 1965). Results are shown in Table 4.

Isotopic values from dolomite and calcite in the carbonate samples show $\delta^{18} \mathrm{O}$ and $\delta^{13} \mathrm{C}$ values ranging from -7.9 to $3.0 \%$ $\mathrm{PDB}$ and from -9.2 to $-1.7 \%$ PDB respectively. Based on isotopic compositions and facies associations, several groups of samples can be differentiated (Fig. 7):

\section{Group I}

Samples from this group correspond to carbonaterich palaeosols and carbonates deposited in ponds associated with the distal alluvial fan terrigenous facies. The carbonate consists of both calcite and dolomite and shows more negative $\mathrm{d}^{13} \mathrm{C}$ values for calcite (from- 9.\%o to -7.4\% PDB) than for dolomite (from -7.5 to $-5.9 \%$ PDB), whereas the oxygen composition is highly variable, ranging from -7.9 (calcite) to 0.6\% PDB (dolomite). Some samples, showing very negative values for both carbon and oxygen, come from carbonate-rich palaeosols in which calcite is present as extensively developed pseudospheru- lite mosaics. The isotopic composition of these pseudospherulites is similar to that reported from

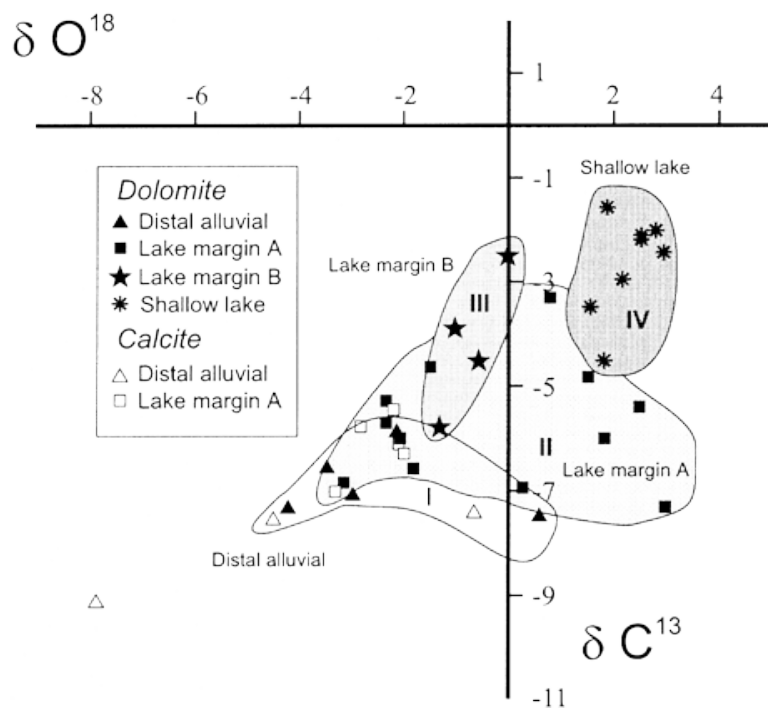

Fig. 7. $\delta^{18} \mathrm{O}-\delta^{13} \mathrm{C}$ cross-plot of carbonate samples from lacustrine and associated alluvial fan facies of the Miocene from the Orera-Valdelosterreros area. Four distinct groups with some overlaps are distinguished based on isotopic composition and facies of the carbonate deposits (see text for explanation).

pseudospherulitic fibrous calcite in other Tertiary formations (Rossi \& Cañaveras, 1999). According to these authors, the depleted oxygen isotopic compositions can be considered typical of meteoric-derived calcites, and the negative $\mathrm{d}^{13} \mathrm{C}$ values may reflect the influence of ${ }^{12} \mathrm{C}$-enriched soil-derived meteoric waters. On the other hand, the carbonate-rich palaeosols (dolocretes) hosting pseudospherulites show more positive $\mathrm{d}^{18} \mathrm{O}$ values (Table 4), which would reflect evaporative enrichment in $\delta^{18} \mathrm{O}$, probably under the influence of the adjacent moderately saline lake (Spötl \& Wright, 1992; Calvo et al., 1995; Alonso-Zarza et al., 1998).

\section{Group II}

Samples of this group correspond to carbonates deposited in a lake margin (lake margin lithofacies association A), which extended in front of alluvial fan systems. Except for a few palustrine palaeosols where calcite is more prominent, most of the samples consist exclusively of dolomite. The wide range of carbon and oxygen stable isotope compositions of these carbonate deposits (Fig. 7) reflects the variable subenvironments of carbonate deposition. Only one sample (TS-03, Table 4), showing heavier carbon and oxygen isotope values for dolomite, falls outside the general trend displayed by the carbonate samples of this group. Overall, moderately negative $\delta^{13} \mathrm{C}$ 
values of the carbonates suggest incorporation of organic-derived ${ }^{13} \mathrm{C}$-depleted carbon, which is in agreement with the pedogenic features recognized in these deposits. The relative dispersion of $\delta{ }^{18} \mathrm{O}$ values may indicate a mixture between evaporite brine and meteoric waters (Coniglio et al., 1988). In fact, heavier $\delta^{18} \mathrm{O}$ values are found in massive nodular dolomite, representative of lake deposits subject to slight episodic desiccation, whereas other carbonate facies, with more definite palustrine and/or subaerial exposure imprints, e.g. pedogenic features, tepees, fenestral fabrics, have lower $\delta^{18} \mathrm{O}$ values, indicative of episodic input of freshwater in the lake margin environment. Partial overlap of the isotopic values of carbonate deposits of the lake margin lithofacies association A with other groups of samples (Fig. 7) points to a close palaeohydrological relationship among the different carbonate lithologies.

\section{Group III}

Samples from this group correspond to carbonates of lake margin lithofacies association B that extend laterally from alluvial fan deposits and pass into more open lacustrine facies. The carbonate deposits consist only of dolomite with $\delta^{13} \mathrm{C}$ values ranging from -5.8 to $-2.5 \%$ pDB, whereas $\delta^{18} \mathrm{O}$ values are confined to a narrow range from -1.3 to $0.0 \%$ PDB (Fig. 7 ; Table 4). The moderately low $\mathrm{d}^{13} \mathrm{C}$ values suggest that carbonate formation was not related to either sulphate reduction or methanogenesis, which would produce lighter isotopic signatures than those obtained (Pierre et al., 1984). The relatively wide range of negative carbon isotope ratios suggests variable contribution of soil-derived $\mathrm{CO}_{2}$, which agrees with the episodic development of plant cover in lake margin areas. In contrast, the low variability of the $\delta^{18} \mathrm{O}$ record (range of $1.3 \%$ ) reflects moderate changes in water temperature, salinity and the hydrological balance (inflow precipitation) between periods of carbonate precipitation.

\section{Group IV}

Samples in this group correspond to carbonate deposited in shallow lake environments. The dolomite samples (Table 4) show slightly negative $\mathrm{d}^{13} \mathrm{C}$ values (from -4.5 to $-1.7 \%$ PDB) and more positive $\delta^{18} \mathrm{O}$ values (from 1.6 to $2.9 \%$ PDB) defining a separate group of isotopic compositions (Fig. 7). The relatively high carbon isotope ratios indicate a minor contribution of biogenic $\mathrm{CO}_{2}$ to the total dissolved inorganic carbonate (TDIC) reservoir. In lakes of closed and semiclosed basin systems with a long residence time, such as in this case, enrichment in $\delta^{13} \mathrm{C}$ values may be induced by primary production of organic matter (McKenzie, 1985) or non-equilibrium degassing of ${ }^{12} \mathrm{C}$ to the atmosphere (Talbot \& Kelts, 1990) associated with a low water table during evaporation. On the other hand, removal of $\mathrm{CO}_{2}$ by degassing from the interstitial, $\delta^{13} \mathrm{C}$ depleted solutions tends to enrich the remaining TDIC in ${ }^{13} \mathrm{C}$ by mass balance effect (Deines et al., 1974; Pierre et al., 1984).

The positive $\mathrm{d}^{18} \mathrm{O}$ values shown by the shallowlake carbonates indicate intense evaporitic conditions or prolonged residence time of lake water (Last, 1990; Anadón \& Utrilla, 1993). Evaporative concentration, leading to saline conditions, is usually recorded by an enrichment of ${ }^{18} \mathrm{O}$ of the precipitated carbonate phases. The precipitation of the lacustrine Orera dolomites most likely resulted from evaporative concentrated surface and groundwaters and could thus be considered 'evaporitic' dolomites as reported from other recent and ancient lake systems (Rosen et al., 1989; Warren, 1990; Anadón \& Utrilla, 1993).

Finally, the isotope values support the subaqueous origin of the dolomitic carbonates as suggested in the depositional model.

The wide range in the $\mathrm{d}^{18} \mathrm{O}$ and $\delta^{13} \mathrm{C}$ values of the lacustrine system reflects the relatively broad variation of palaeoenvironments and processes involved in isotopic fractionation. As a whole, the isotopic data from the Orera dolomites show partial overlap with data obtained for other dolomites in the rest of the Calatayud Basin, with $\mathrm{d}^{18} \mathrm{O}$ and $\mathrm{d}^{13} \mathrm{C}$ values showing narrower ranges of $-5.5 \%$ to $-1 \%$ PDB and $-4.5 \%$ to $-0.2 \%$ PDB (Sanz-Rubio, 1999) respectively. However, they agree with isotope values determined for dolomites in the same study area (Mayayo et al., 1996). Covariance of $\delta^{18} \mathrm{O}$ and $\delta^{13} \mathrm{C}$ values is particularly remarkable in dolomites from groups III and IV (lake margin $\mathrm{B}$ and shallow lake lithofacies respectively), thus supporting the interpretation that the lake basin evolved under hydrologically closed conditions (Talbot \& Kelts, 1990; Li \& Ku, 1997). The positive $d^{18} \mathrm{O}$ values for dolomite plot in the same range $(1.5-3.0 \%)$ as middle Miocene carbonate deposits in the nearby Ebro basin (Arenas et al., 1997). Furthermore, a clear tendency for ${ }^{18} \mathrm{O}$ enrichment of the dolo- mites has been determined towards the centre of the Orera lake basin. This trend differs from the 
isotopic trend in the Steinmergel-Keuper of southern Germany, where a progressive $\delta^{18} \mathrm{O}$ depletion is observed from playa margin to playa lake (Reinhardt \& Ricken, 2000).

Based on the sedimentary interpretations and the stable isotopes results, a depositional model for the mudstone-carbonate cycles of the cyclic mudflat-shallow lake facies is presented.

\section{DEPOSITIONAL MODEL FOR THE MUDSTONE-CARBONATE CYCLES}

In arid to semi-arid climate regions, evaporation in closed lake basins usually exceeds water inflow through run-off and/or streams and is therefore highly sensitive to variations in the evaporation/precipitation balance (GierlowskiKordesch \& Kelts, 1994). Low-gradient, shallow lake basin environments, such as depicted for the Orera area, are sensitive to minor fluctuations in lake level; even a slight drop in lake level may result in exposure of large areas of the lake margin and possibly the lake floor. The small-scale mudstone-carbonate cycles in Orera indeed suggest that lake-level fluctuations played an important role in their formation. Considering the remarkable regularity of the cycles, it is suggested that climate change is the driving force behind the lake-level fluctuations and thus the formation of the cycles. In the following paragraphs, the sedimentary features in the mudstone-carbonate cycles are discussed by comparing them with past and modern analogues, and a depositional model for the cycles is presented (Fig. 8).

\section{Siliciclastic mudstones}

Primary structures in the siliciclastic mudstone deposits are poorly preserved, yet evidence for bioturbation, including rootlet traces, is abundant. The mudstone beds are green-grey or red and reddish-brown in colour and contain rare clay and micrite peloids. These features are similar to those described in mudstone-bearing cycles from the Late Triassic Norian Mercia Mudstone Group of Somerset in England (Wright \& Sandler, 1994; Talbot et al., 1994), the Triassic Steinmergel-Keuper in Germany (Reinhardt \& Ricken, 2000) and the Quaternary interior lake basins in east-central Australia (Talbot et al., 1994). In the last setting, mudstones are inferred to have been deposited on wide, low-gradient, partially vegetated plains. As observed by Nanson

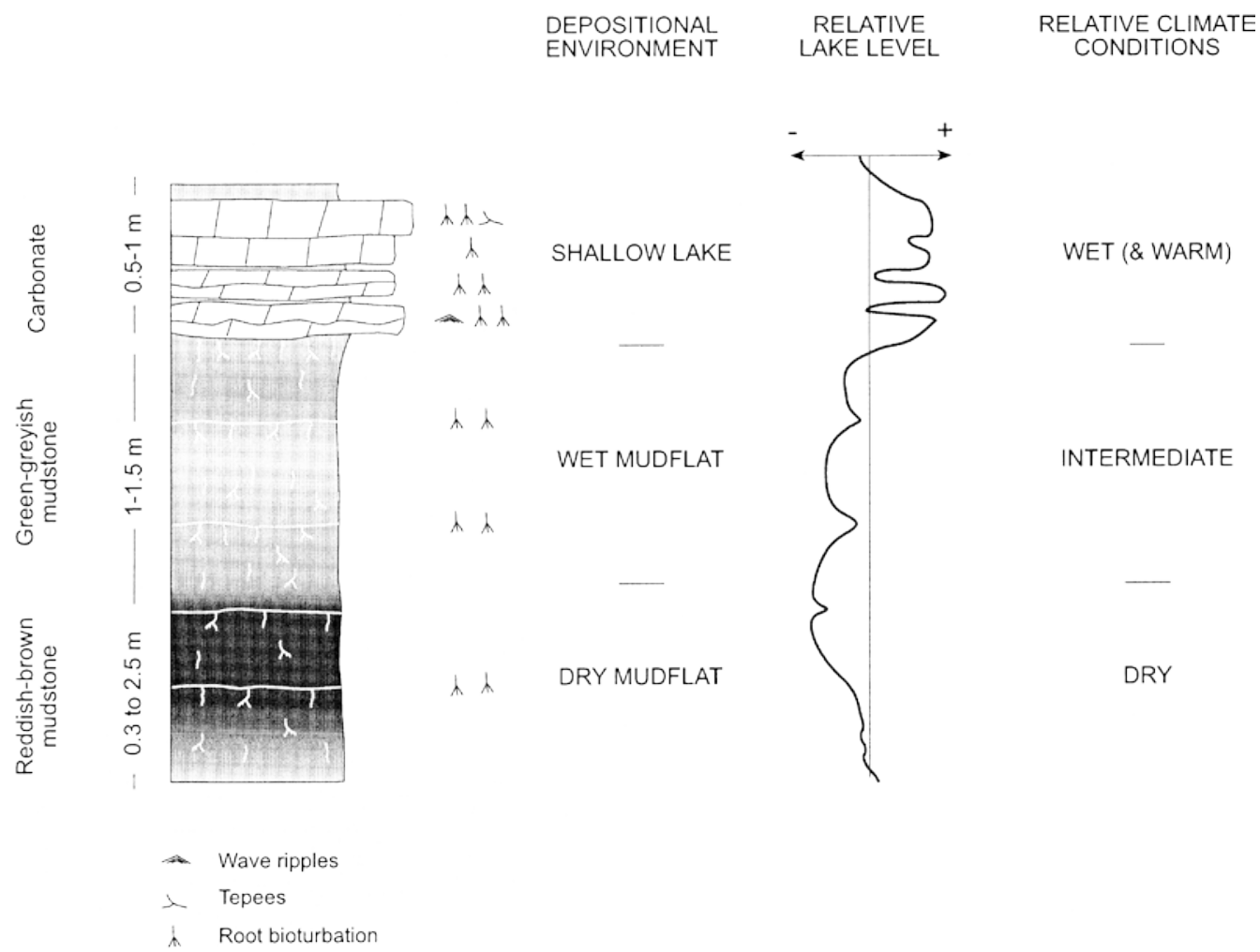

Fig. 8. Schematic diagram and sedimentological and palaeoclimatic interpretation of a basic small-scale sedimentary cycle of the mudflat-shallow lake facies of the Miocene at Orera. See text for details. 
et al. (1988) and Rust \& Nanson (1989), mud deposition involved the transport of mud aggregates by bedload and settling of suspended sediment from ponded floodwaters.

The green-greyish and reddish-brown mudstones in Orera are interpreted to have been deposited by sheetfloods on low-gradient, vegetated mudflats during dry climatic conditions (Fig. 8). The green-grey muds were transported by episodic floods and deposited on wet (saline) mudflats. The numerous tepees present in the lake margin (lithofacies B) areas of the Orera study area provide evidence for the influence of groundwater, a likely source of moisture to develop a water-saturated mudflat in which reducing conditions accounted for the green-grey colour of the mudstone. This is in agreement with the hydrogeological model developed by Wright \& Sandler (1994) for the Australian interior basins located at approximately the same (opposite) latitudes as the Calatayud Basin during Miocene times. This model, which requires a regular Mg-ion supply by evolved groundwaters with high ion concentration and $\mathrm{pH}$ during dry seasons, could also explain the high content of Mg-clays in the Orera mudstones. The green-grey colour of the mudstone may also be related to poor drainage conditions, often a characteristic feature in closed basin systems (Hardie et al., 1978).

The reddish-brown siliciclastic mudstones were transported by low-energy floods and deposited on subaerially exposed dry mudflats where oxidizing conditions prevailed. Root bioturbation in these mudstones is not as abundant as in the green-grey mudstones, which probably results from lack of moisture to support continuous vegetation because of lowering of the groundwater table during drought periods. Punctuated wetter climatic conditions (Fig. 8) may have raised the groundwater level, favouring hydromorphic processes and local colonization by plants. The upper parts of reddish-brown mudstones mostly pass gradationally up into thin dark grey-green mudstones before being overlain by tabular carbonate beds. This gradation may imply that the original colour of the mudstone was transformed as a result of oxide-reducing conditions. It is questionable whether all the green-grey mudstone in the Orera study area was initially reddish-brown in colour because of the gradual transition from reddish-brown to greengrey mudstone and the fact that the 'reduced' top part of the reddish-brown mudstones is often only a few centimetres thick.
During lake level lowstand, lake margin areas (lithofacies B) also underwent subaerial exposure. Red siliciclastic mudstones are found in both the cyclic mudflat-shallow lake facies and the lake margin facies (Fig. 4), suggesting that mudflats periodically extended their range over the lake margin areas. The distal alluvial fan environments were dominated by sandflats.

\section{Dolomitic carbonates}

The dolomitic carbonates in the cyclic deposits of Orera show a variety of facies, from massive to nodular and vaguely laminated with local tepee structures. The dolomite beds are laterally continuous over large distances, thus supporting an origin from a standing, shallow-water body. Moreover, the dolomitic carbonates in the cyclic facies of Orera typically display a uniform micritic grain texture characteristic of dolomitic muds presently formed subaqueously in shallow, brackish to saline lakes of the Coorong region of south Australia (Von der Borch \& Lock, 1979; Wright, 1999) and other lake basins in the Australian interior (De Deckker \& Last, 1989; Rosen \& Coshell, 1992). The isotopic composition of the Orera dolomites (group IV; Fig. 7) suggests that the carbonate precipitated from progressively concentrated waters. A subaqueous origin is supported by other features in the Orera carbonates, such as the scarce remains of charophytes and gastropods, indicative of brackish to freshwater conditions, and infrequent organic-rich laminae implying seasonal climate. Hence, the dolomitic carbonates of Orera are interpreted as shallow-water deposits, which accumulated in a lake that extended over alluvial mudflats during relatively humid climate conditions (Fig. 8). This assessment is in agreement with the interpretations for the mudstone-carbonate cycles from the Mercia Mudstone Group of Somerset (Talbot et al., 1994) and the Steinmergel-Keuper of southern Germany (Reinhardt \& Ricken, 2000). The carbonates may indicate a period of stabilized lake environment, during which clastic input was reduced probably as the result of an increase in floral density that limited erosion. At the onset of drier climate conditions, lake level dropped, and carbonate accumulation ceased, leading to periods of subaerial exposure of the top of some carbonate beds. Support for carbonate deposition occurring during wet periods comes from the gradational transition from mudstone to dolomite, which is commonly marked by intense rooting and sometimes intercalation of abundant 
plant debris. A similar transition is recognized between mudstones and carbonates in the Late Triassic Norian Mercia Mudstone Group of Somerset (Talbot et al., 1994).

The bed-to-bed correlation between tabular carbonate beds of the cyclic shallow-lake facies and those of the lake margin (Fig. 4) indicates that lake margin areas were also submerged during periods of lake highstand. The development of small isolated ponds and the formation of (extensive) palustrine carbonates in the most distal areas of the alluvial fan probably also relate to the influence of an expanding lake and/or the associated rise in groundwater level.

\section{Sedimentation rates}

Glenn \& Kelts (1991) emphasized the fact that sedimentation rates within different lake facies in closed lake basins may vary considerably and that care must be taken in evaluating the thickness of different lithofacies sequences with respect to time. The cyclic shallow-lake carbonates in the Orera composite section (OCS) locally display features of subaerial exposure, suggesting that some time may not be recorded in the upper parts of these carbonates. However, the lateral continuity and relatively constant thickness of the carbonate beds in combination with the absence of clear pedogenic profiles exclude very long periods of exposure and major hiatuses in the succession. More likely, only minor hiatuses are present locally, which represent just a small part of the time covered by the individual basic mudstone-carbonate cycles. Apart from possible minor hiatuses, only average accumulation rates can be calculated for each mudstone-carbonate cycle in the OCS, whereas the accumulation rates for different lithologies within a cycle (i.e. mudstone or carbonate) cannot be determined.

Sedimentation rates in the OCS succession can be determined using the calibration of the OCS magnetostratigraphy with the geomagnetic polarity time scale (GPTS) of Cande \& Kent (1995) (Abdul Aziz et al., 2000). This calibration indicated that the succession was deposited in $\approx 2,1$ million years (Abdul Aziz et al., 2000); hence, the average sedimentation rate for the entire composite section remains fairly constant at 7,4 $\mathrm{cm} \mathrm{kyr}^{-1}$ (Fig. 9). Despite minor uncertainties in the sedimentation rate, because of the local presence of small hiatuses, the fairly constant sedimentation rate, the shallow character of the depositional environment and the extraordinary regularity of the sedimentary cyclicity point to a remarkable

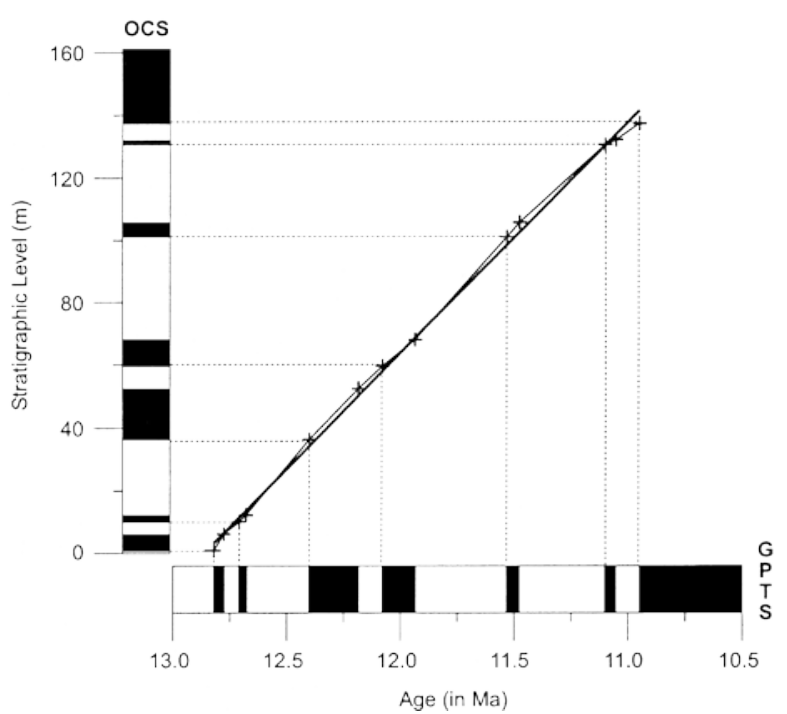

Fig. 9. Diagram showing changes in sedimentation rates for the Orera composite section (OCS) through time. Thick black line denotes the average sedimentation rate, which is $7.4 \mathrm{~cm} \mathrm{kyr}^{1}$. Sedimentation rates are determined from plotting the stratigraphic thick- ness of the OCS record vs. the calibrated geomagnetic polarity time scale (GPTS) ages of Cande \& Kent (1995) (after Abdul Aziz et al., 2000). In the polarity columns, black denotes normal polarity and white reversed polarity.

balance between sediment supply and accommodation space.

\section{PALAEOENVIRONMENTAL RECONSTRUCTION}

The sedimentary cycles present in Orera are interpreted as shallow lake and mudflat deposits that grade laterally into lake margin facies (lake margin lithofacies association B) and further into alluvial fan deposits. The latter deposits are related to the Orera alluvial fan system, the apex of which encroaches upon the northern margin of the Calatayud Basin (Figs 1 and 10). A similar stratigraphic and geometrical relationship is observed between the lower part of the cyclically bedded succession and the alluvial deposits of the Miedes Fan, which extends south-east of the area. The Miedes Fan is a NE-SW-trending major feature, the fan head of which is located near Codos (Fig. 1). Like the Orera Fan, most distal alluvial fan lithofacies interfinger with lake margin lithofacies (lake margin lithofacies association A) forming a continuous belt in front of the alluvial fans. In this picture (Fig. 10), the cyclic shallow lake deposits occupy a position in 


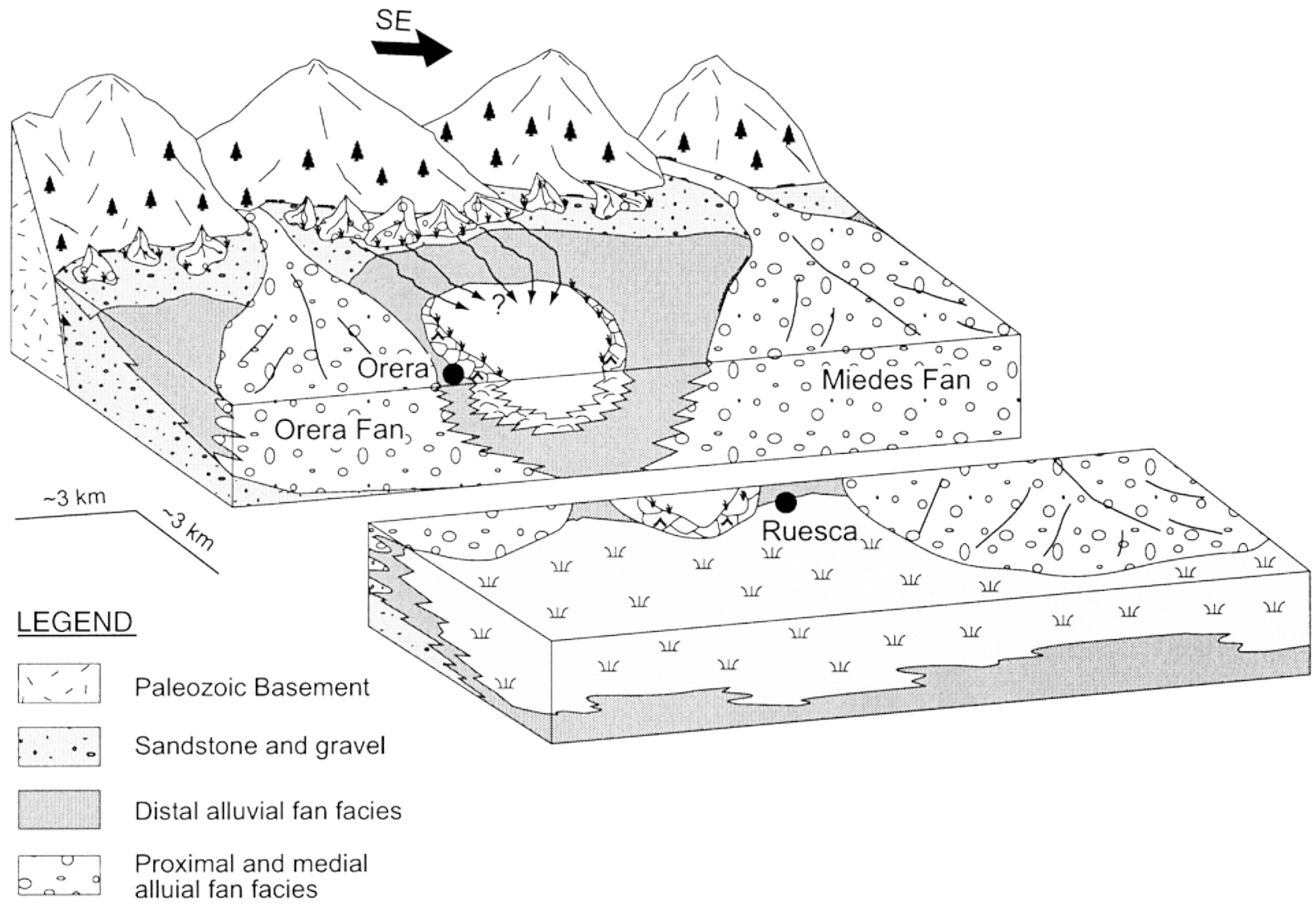

\section{Cyclic shallow lake lithofacies \\ W L Lake margin lithofacies A \\ Lrake margin lithofacies B}

Fig. 10. Schematic block diagram showing the palaeoenvironmental reconstruction of the Orera area during the Middle Miocene. The cyclic sedimentary succession of Valdelosterreros (section IV in Fig. 4) accumulated in a shallow lake basin that developed in a 'shadow zone' between the two major alluvial fans of Orera and Miedes. The northern part of the lake basin is considered as a preferential pathway (arrows) for supply of most sediment into the lake.

between the Orera and Miedes fans. This area can be considered an interfan or 'shadow zone' (Hooke, 1967; Alonso-Zarza et al., 1993), lateral to the influence of alluvial sedimentation from the two main fans, resulting in a depressed area in which a small lake basin developed. This palaeoenvironmental and palaeogeographic reconstruction is supported by the fact that the lake deposits extend laterally towards the north, where small coalesced alluvial cones fringe the (local) basin margin. A recent analogue for this particular type of interfan lake basin is Lake Manly in Death Valley, California (Blair, 1999). Similar small lake basins located in interfan positions are found within the Sillwater fans system in Nevada (Harvey et al., 1999) and are associated with the Arcas fan in the Andean forearc of northern Chile
(Kiefer et al., 1997). Examples from the ancient sedimentary record have been documented by McGowen \& Groat (1971) from the Van Horn Sandstone, West Texas, and by Seni (1980) from the Neogene Ogalalla formation in Texas.

The development of the small lake basin was most likely constrained by aggradation of the Orera and Miedes alluvial fan systems, which extended from the north-eastern margin into the Calatayud Basin. The NW-SE-trending normal faults, which delineate the basin margin, inevitably influenced the position and setting of these alluvial fans (cf. Bull, 1977; Harvey, 1987). In the study area, no direct evidence was found for structural elements that could have controlled subsidence of the area of the small lake basin in Orera. However, the presence of a 
NNE-SSW-oriented fault in the river valley west of the village of Orera (Fig. 3) cannot be excluded. This potential fault may be linked to a fault in the Palaeozoic basement north of Orera (Instituto Geoló gico Minero de Españ a, 1983). Nevertheless, biostratigraphic data from a locality in lake margin lithofacies A (Canudo \& Cuenca, 1989) show that this fault alone could not have accounted for the development of the small lake basin. The micromammal fossils indicate an upper Aragonian to Vallesian age (Peláez-Campomanes et al., 2000), which coincides with approximately the middle part of section IV (Fig. 4). Furthermore, the sedimentary cyclicity observed in lake margin successions exposed on both sides of the river valley is similar and resembles the cyclicity of the shallow lake facies. Unambiguous bed-to-bed correlation between the cycles of lake margin lithofacies B (section III) and shallow lake lithofacies (sections IV and V) (Fig. 4) suggests that alluvial fan aggradation most likely provided the accommodation space necessary for the deposition of the shallow lake lithofacies.

Geometrical relationships between the different lithofacies indicate that deposition took place in a low-gradient, shallow lake basin where the supply of siliciclastic sediment was mainly derived from the area north of the basin (Fig. 10). This direction of supply is supported by a west-east increase in thickness of the green-grey siliciclastic mudstone units from lake margin lithofacies B towards the small lake basin. Because the deposits of the marginal lithofacies B are located east of and lateral to the Orera Fan, this fan can be excluded as a major source of sediment (Fig. 10). The Miedes Fan can also be excluded because the fan axis is relatively distant from the shallow lake basin and extends in a south-west direction far into the Calatayud Basin, thereby bypassing the small lake area. In contrast, from north to south, a gradual decrease in thickness of siliciclastic mudstone and siltstone units together with a gradual transition from reddish-brown silty mudstone beds to green-greyish mudstone is observed, the colour change reflecting a zonation of subaerially exposed marginal and mudflat-lacustrine environments. The carbonate units show, in both west-east and north-south directions, a very gradual change in thickness and facies types. Moreover, the isotopic compositions of the carbonates vary according to the arrangement and spatial distribution of facies, showing both ${ }^{18} \mathrm{O}$ and ${ }^{13} \mathrm{C}$ enrichment basinwards (Fig. 7). The wide spread of oxygen and carbon isotope composi- tions in carbonates that accumulated in the front of alluvial fans is in agreement with the variety of depositional subenvironments in such a depositional setting. Except for the irregular upper surfaces (mounds) observed locally in carbonate beds of lake margin lithofacies B (see Fig. 6B), carbonate beds typically exhibit a tabular geometry that can be followed for hundreds of metres. Finally, the progressive decrease in subaerial exposure features (i.e. palustrine imprint of Freytet \& Plaziat, 1982) observed in carbonate beds from marginal to more central lake settings is typical of low-gradient, ramp-type lake margin environments (Platt \& Wright, 1991).

\section{CONCLUSIONS}

1 The middle Miocene sediments in the Orera study area are divided into four lithofacies associations: proximal and medial alluvial fan facies, distal alluvial fan facies, lake margin facies with two distinct lithofacies associations and cyclic shallow lake facies. The cyclicity in the last facies is defined by an alternation of red/reddish-brown and/or green-grey mudstone and white carbonate (dolomite). Isotopic compositions of the carbonates present in the several facies associations range from - 7.9 to $3 \%$ PDB for $\delta^{18} \mathrm{O}$ and from) 9,2 to $-1,7 \%$ PDB for $\delta^{13} \mathrm{C}$. The more negative isotopic values come from palaeosols in the distal alluvial fan facies and from lake margin carbonate beds, whereas more positive isotope values are recorded in dolomite beds from the cyclic shallow lake facies, reflecting lateral facies changes from marginal to more central lake areas.

2 The mudstone-carbonate cycles are the result of lake-level variations caused by periodic changes in climate. To establish the link between the siliciclastic mudstone and carbonate beds on the one hand and climate on the other, a depositional model is presented for the mudstone-carbonate cycles of the shallow lake facies. This model implies that siliciclastic mudstone accumulated on vegetated mudflats during relatively dry climatic conditions. Low-energy floods transported the mud from adjacent alluvial fans to the surrounding, vegetated mudflats. The reddish-brown mudstones indicate that deposition occurred on dry mudflats, whereas the green-grey mudstones were deposited on wet mudflats. The change towards relatively wetter conditions resulted in the development of a shallow lake on the former mudflats. 
3 Accumulation of the cyclic succession took place in a low-gradient ramp-type basin, which developed in an interfan zone between two major alluvial fans. The continuous sedimentation throughout most of the succession, inferred from sedimentological features and high-resolution magnetostratigraphy, and the shallow lacustrine setting indicate that a particular balance between sedimentation and subsidence rates was maintained and that alluvial fan aggradation played an important role in providing the necessary accommodation space.

4 It is suggested that the distribution of the various lithofacies in the study area is linked to fluctuating lake levels controlled by periodic changes in climate. Ideally, precise time control and bed-to-bed correlations between the sedimentary cycles in all different lithofacies-defined palaeoenvironments are essential to determine the relationship with climate.

\section{ACKNOWLEDGEMENTS}

We acknowledge M. Pozo for his assistance in evaluating clay mineral results. Ana M. Alonso Zarza is thanked for help in fieldwork and further comments on the interpretation of the lacustrine sediments. J. E. Meulenkamp, P. L. de Boer and A. Arche are thanked for their comments on the manuscript. We are also very grateful to Elizabeth Gierlowsky-Kordesch, Chris Fielding and an anonymous reviewer for their thorough reviews and constructive comments. The collaboration of Luis Luque and Sander Ernst in sampling is greatly appreciated. This research has been supported by Spanish projects PB97-0244, PB98-0503 and PB980691-CO3-03 financed by DGESIT, and by the Earth and Life Sciences Foundation (ALW) with financial aid from the Netherlands Organisation for Scientific Research (NWO).

\section{REFERENCES}

Abdul Aziz, H. (2001) Astronomical forcing in continental sediments. (An integrated study of Miocene deposits from the Calatayud and Teruel basins, NE Spain). Geologica Ultraiectina, 207, Utrecht, The Netherlands ( $\mathrm{PhD}$ Thesis).

Abdul Aziz, H., Hilgen, F.J., Krijgsman, W., Sanz-Rubio, E. and Calvo, J.P. (2000) Astronomical forcing of sedimentary cycles in the middle to late Miocene continental Calatayud Basin (NE Spain). Earth Planet. Sci. Lett., 177, 9-22.

Allen, J.R.L. (1986) Pedogenic calcretes in the Old Red Sandstone Facies (Late Silurian-Early Carboniferous) of the
Anglo-Welsh area, southern Britain. In: Paleosols. Their Recognition and Interpretation (Ed. V.P. Wright), pp. 58-86. Blackwell Science Publishers, Oxford.

Alonso-Zarza, A.M. and Calvo. J.P. (2000) Palustrine sedimentation in an episodically subsiding basin: the Miocene of the northern Teruel graben. Palaeogeogr. Palaeoclimatol. Palaeoecol., 160, 1-21.

Alonso-Zarza, A.M., Calvo, J.P. and García del Cura, M.A. (1992) Palustrine sedimentation and associated features grainification and pseudo-microkarst - in the Middle Miocene (Intermediate Unit) of the Madrid Basin, Spain. Sed. Geol., 76, 43-61.

Alonso-Zarza, A.M., Calvo. J.P. and García del Cura, M.A. (1993) Palaeogeomorphological controls on the distribution and sedimentary styles of alluvial systems, Neogene of the NE of the Madrid Basin (central Spain). In: Alluvial Sedimentation (Eds M. Marzo and C. Puigdefábregas), Spec. Publ. Int. Assoc. Sedimentol., 17, 277-292.

Alonso-Zarza, A.M., Sanz, M.E., Calvo, J.P. and Estévez, P. (1998) Calcified root cells in Miocene pedogenic carbonates of the Madrid Basin: evidence for the origin of Microcodium b. Sed. Geol., 116, 81-97.

Anadón, P. and Moissenet, E. (1996) Neogene basins in the Eastern Iberian Range. In: Tertiary Basins of Spain: the Stratigraphic Record of Crustal Kinematics (Eds P.F. Friend and C.J. Dabrio). World and Regional Geology 6, pp. 68-76. Cambridge University Press, Cambridge.

Anadón, P. and Utrilla, R. (1993) Sedimentology and isotope geochemistry of lacustrine carbonates of the Oligocene Campins Basin, northeast Spain. Sedimentology, 40, 699-720.

Arenas, C., Casanova, J. and Pardo, G. (1997) Stable-isotope characterization of the Miocene lacustrine systems of Los Monegros (Ebro Basin, Spain): palaeogeographic and palaeoclimatic implications. Palaeogeogr. Palaeoclimatol. Palaeoecol., 128, 133-155.

Assereto, R.L.A.M. and Kendall, C.G.St C. (1977) Nature, origin and classification of peritidal tepee structures and related breccias. Sedimentology, 24, 153-210.

Astin, T.R. (1990) The Devonian lacustrine sediments of Orkney, Scotland: implications for climate cyclicity, basin structure and maturation history. J. Geol. Soc. London, 147, 141-151.

Blair, T.C. (1999) Sedimentology of the debris-flow-dominated Warm Spring Canyon alluvial fan, Death Valley, California. Sedimentology, 46, 941-965.

Blair, T.C. and McPherson, J.G. (1994) Alluvial fans and their natural distinction from rivers based on morphology, hydraulic processes, sedimentary processes, and facies assemblages. J. Sed. Res., 64, 450-489.

Bradley, W.B. (1929) The varves and climate of the Green River epoch. US Geol. Surv. Prof. Paper, 158, 87-110.

Brewer, R. (1964) Fabric and Mineral Analysis of Soils. Wiley, New York, 470 pp.

Bull, W.B. (1977) The alluvial fan environment. Prog. Phys. Geogr., 1, 222-270.

Bull, W.B. (1997) Discontinuous ephemeral streams. Geomorphology, 19, 227-276.

Calvo, J.P., Alonso Zarza, A.M. and García del Cura, M.A. (1989) Models of Miocene marginal lacustrine sedimentation in response to varied depositional regimes and source areas in the Madrid Basin (central Spain). Palaeogeogr. Palaeoclimatol. Palaeoecol., 70, 199-214.

Calvo, J.P., Jones, B.F., Bustillo, M., Fort, R., Alonso Zarza, A.M. and Kendall, C. (1995) Sedimentology and 
geochemistry of carbonates from lacustrine sequences in the Madrid Basin, central Spain. Chem. Geol., 123, 173-191.

Calvo, J.P., Abdul Aziz, H., Hilgen, F.J., Sanz-Rubio, E. and Krijgsman, W. (1999a) The Orera section (Calatayud Basin, NE Spain): a remarkable cyclically bedded lacustrine succession from the Spanish Miocene. In: Towards the Balanced Management of the Geological Heritage in the New Millennium (Eds D. Barettino, M. Vallejo and E. Gallego), pp. 186-192. Sociedad Geológica de España-IGMEPROGEO, Madrid.

Calvo, J.P., Blanc-Valleron, M.M., Rodríguez-Aranda, J.P., Rouchy, J.M. and Sanz, M.E. (1999b) Authigenic clay sedimentation in evaporitic environments. In: Palaeoweathering, Palaeosurfaces and Related Continental Deposits (Eds M. Thiry and R. Simon-Coinçon), Spec. Publ. Int. Assoc. Sedimentol., 27, 129-152.

Cande, S.C. and Kent, D.V. (1995) Revised calibration of the geomagnetic polarity timescale for the Late Cretaceous and Cenozoic. J. Geophys. Res., 100, 6093-6095.

Canudo, J.I. and Cuenca, G. (1989) Nota preliminar de un nuevo yacimiento Vallesiense en la fosa de CalatayudMontalbán. Separata de Segundo Encuentro de Estudios Bilbilitanos. Calatayud, Spain, pp. 157-160.

Capote, R. (1983) La tectónica de la Cordillera Ibérica. In: Geología de España, Tomo II (Ed. Instituto Geoló gico y Minero de Españ a), pp. 108-120. Instituto Geoló gico y Minero de España, Madrid.

Colson, J. and Cojan, I. (1996) Groundwater dolocretes in a lake-marginal environment: an alternative model for dolocrete formation in continental settings (Danian of the Provence Basin, France). Sedimentology, 43, 175-188.

Coniglio, M., James, N.P. and Aissaoui, D.M. (1988) Dolomitization of Miocene carbonates, Gulf of Suez, Egypt. J. Sed. Petrol., 58, 100-119.

De Deckker, P. and Last, W.M. (1989) Modern, non-marine dolomite in evaporitic playas of western Victoria, Australia. Sed. Geol., 64, 223-238.

Deines, P., Langmuir, D. and Rusell, S.H. (1974) Stable carbon isotope ratios and the existence of a gas phase in the evolution of carbonate groundwaters. Geochim. Cosmochim. Acta, 38, 1147-1164.

Demicco, R.V. and Gierlowski-Kordesch, E. (1986) Facies sequences of semi-arid closed basin: the Lower Jurassic East Berlin Formation of the Hartford Basin New England, USA. Sedimentology, 33, 107-118.

Doblas, M. and Oyarzun, R. (1990) The late Oligocene-Miocene opening of the North Balearic Sea (Valencia Basin, western Mediterranean): a working hypothesis involving mantle upwelling and extensional detachment tectonics. Mar. Geol., 94, 155-163.

Doblas, M., López-Ruíz, J., Hoyos, M., Martín, C. and Cebriá, J.M. (1991) Late Cenozoic indentation/escape tectonics in the eastern Betic Cordilleras and its consequences on the Iberian foreland. Estud. Geol., 47, 193-205.

Esteban, M. and Klappa, C. (1983) Subaerial exposure environment. In: Carbonate Depositional Environments (Eds P.A. Scholle, D.G. Bebout and C.H. Moore), Am. Assoc. Petrol. Geol. Mem., 33, 1-54.

Fischer, A.G. and Roberts, L.T. (1991) Cyclicity in the Green River Formation (lacustrine Eocene) of Wyoming. J. Sed. Petrol., 61, 1146-1154.

Freytet, P. and Plaziat, J.C. (1982) Continental carbonate sedimentation and pedogenesis - Late Cretaceous and early Tertiary of southern France. Contrib. Sedimentol., 12, 213 pp.
García del Cura, M.A., Calvo, J.P., Ordóñez, S., Jones, B.F. and Cañ averas, J.C. (2001) Petrographic and geochemical evidence for the formation of primary, bacterially induced lacustrine dolomite: La Roda 'white earth' (Pliocene, central Spain). Sedimentology, 48, 897-916.

Gierlowski-Kordesch, E. (1991) Ichnology of an ephemeral lacustrine/alluvial plain system: Jurassic East Berlin Formation, Hartford Basin, USA Ichnos, 1, 221-232.

Gierlowski-Kordesch, E. (1998) Carbonate deposition in an ephemeral siliciclastic alluvial system: Jurassic Shuttle Meadow Formation, Newark Supergroup, Hartford Basin, USA. Palaeogeogr. Palaeoclimatol. Palaeoecol., 140, 161-184.

Gierlowski-Kordesch, E. and Kelts, K. (1994) Introduction. In: Global Geological Record of Lake Basins, Vol. 1 (Eds E. Gierlowski-Kordesch and K. Kelts), pp. xvii-xxxiii. Cambridge University Press, Cambridge.

Gierlowski-Kordesch, E. and Rust, B.R. (1994) The Jurassic East Berlin Formation, Hartford Basin, Newark Supergroup (Connecticut and Massachusetts): a saline-playa-alluvial plain system. In: Sedimentology and Geochemistry of Modern and Ancient Saline Lakes (Eds R. Renaut and W.M. Last), SEPM Spec. Publ., 50, 249-265.

Gile, L.H., Peterson, F.F. and Grossman, R.B. (1966) Morphological and genetic sequences of accumulation in desert soils. Soil Sci., 100, 347-360.

Glenn, C.R. and Kelts, K. (1991) Sedimentary rhythms in lake deposits. In: Cycles and Events in Stratigraphy (Eds G. Einsele, W. Ricken and A. Seilacher), pp. 188-221. Springer-Verlag, Berlin.

Gore, P.J.W. (1989) Towards a model of open- and closedbasin deposition in ancient lacustrine sequences: the Newark Supergroup (Triassic-Jurassic), eastern North America. Palaeogeogr. Palaeoclimatol. Palaeoecol., 70, 29-52.

Hardie, L.A., Smoot, J.P. and Eugester, H.P. (1978) Saline lakes and their deposits: a sedimentological approach. Spec. Publ. Int. Assoc. Sedimentol., 2, 7-41.

Harvey, A.M. (1987) Patterns of Quaternary aggradational and dissectional landform development in the Almeria region, southeast Spain: a dry-region tectonically active landscape. Die Erde, 118, 193-215.

Harvey, A.M., Wigand, P.E. and Wells, S.G. (1999) Response of alluvial fan systems to the late Pleistocene to Holocene climatic transition: contrasts between the margins of pluvial Lakes Lahontan and Mojave, Nevada and California, USA. Catena, 26, 255-281.

Hooke, R.L. (1967) Processes in arid region alluvial fans. J. Geol., 75, 438-460.

Hoyos, M. and López Martínez, N. (1985) Iberic Depression. In: Neogene of the Mediterranean Tethys and Paratethys Stratigraphic Correlation Tables and Sediment Distribution Maps (Eds F.F. Steininger, J. Senes, K. Kleeman and F. Rögl), Int. Correl. Program, IUGS, Project 25, 2, 27.

Hoyos, M., Doblas, M., Sá nchez-Moral, S., Cañ averas, J.C., Ordoñ ez, S., Sesé, C., Sanz, E. and Mahecha, V. (1996) Hydration diapirism: a climate-related initiation of evaporite mounds in two continental Neogene basins of central Spain. In: Salt Tectonics (Eds G.I. Alsop, D.J. Blundell and I. Davison), Geol. Soc. Am. Spec. Publ., 100, 49-63.

Hubert, J.F. and Hyde, M.G. (1982) Sheet-flow deposits of graded beds and mudstones on an alluvial sandflat-playa system: Upper Triassic Blomindon Redbeds, St Mary’s Bay, Nova Scotia. Sedimentology, 29, 457-475.

Instituto Geológico Minero de España (IGME) (1983) Mapa Geológico de España. E. 1:50 000. Hoja 438 (Paniza). Instituto Geológico y Minero de España, Madrid. 
Jones, B.F. (1986) Clay mineral diagenesis in lacustrine sediments. In: Studies in Diagenesis (Ed. F.A. Mumpton), US Geol. Surv. Bull., 1578, 291-300.

Julivert, M. (1954) Observaciones sobre la tectó nica de la Depresión de Calatayud. Arrahona, 3-18.

Kendall, C.G.StC. and Warren, J. (1987) A review of the origin and setting of tepees and their associated fabrics. Sedimentology, 34, 1007-1027.

Kiefer, E., Ibekken, H., Dörr, M.J. and Götze, H.J. (1997) Gravity-based mass balance of an alluvial fan giant: the Arcas Fan, Pampa del Tamarugal, Northern Chile. Rev. Geol. Chile, 24, 165-185.

Krijgsman, W., Garcés, M., Langereis, C.G., Daams, R., van Dam, J., van der Meulen, A.J., Agustí, J. and Cabrera, L. (1996) A new chronology for the middle to late Miocene continental record in Spain. Earth Planet. Sci. Lett., 142, 367-380.

Last, W.M. (1990) Lacustrine dolomite - an overview of modern, Holocene and Pleistocene occurrences. Earth Sci. Rev., 27, 221-263.

$\mathrm{Li}, \mathrm{H} .-\mathrm{C}$. and $\mathrm{Ku}, \mathrm{T} .-\mathrm{L}$. (1997) $\mathrm{d}^{18} \mathrm{O}-\mathrm{d}^{13} \mathrm{C}$ covariance as a paleohydrological indicator for closed-basin lakes. Palaegeogr. Palaeoclimatol. Palaeoecol., 133, 69-80.

McGowen, J.H. and Groat, C.G. (1971) Van Horn Sandstone, West Texas: An Alluvial Fan Model For Mineral Exploration. Report of Investigations 72. Bureau of Economic Geology, The University of Texas at Austin, Austin, TX, 57 pp.

McKenzie, J.A. (1985) Carbon isotopes and productivity in the lacustrine and marine environment. In: Chemical Processes in Lakes (Ed. W.D. Stumm), pp. 99-118. Wiley, New York.

Machette, M.N. (1985) Calcic soils of the southwestern United States. In: Soils and Quaternary Geology of the Southwestern United States (Ed. D.L. Weide), Geol. Soc. Am. Spec. Paper, 203, 1-21.

Marín, A. (1932) Sondeos de Investigación de Sales Potásicas. Boletín de Sondeos TIII. Instituto Geoló gico y Minero de España, Madrid.

Mayayo, M.J., Bauluz, B., López-Galindo, A. and GonzálezLó pez, J.M. (1996) Mineralogy and geochemistry of the carbonates in the Calatayud Basin (Zaragoza, Spain). Chem. Geol., 130, 123-136.

Mayayo, M.J., Torres-Ruíz, J., González-López, J.M., LópezGalindo, A. and Bauluz, B. (1998) Mineralogical and chemical characterization of the sepiolite/Mg-smectite deposit at Mara (Calatayud Basin, Spain). Eur. Mineral., 10, 367-383.

Miall, A.D. (1978) Lithofacies types and vertical profile models in braided river deposits: a summary. In: Fluvial Sedimentology (Ed. A.D. Miall), Can. Soc. Petrol. Geol. Mem., 5, 597-604.

Nanson, G.C., Young, R.W., Price, D.M. and Rust, B.R. (1988) Stratigraphy, sedimentology and late Quaternary chronology of the channel country of western Queensland. In: Fluvial Geomorphology of Australia (Ed. R.F. Warner), pp. 151-175. Academic Press, Sydney.

Olsen, P.E. (1984) Periodicity of lake-level cycles in the late Triassic Lockatong formation of the Newark basin. In: Milankovitch and Climate (Ed. A. Berger), pp. 127-146. D. Reidel, Dordrecht.

Olsen, P.E. (1986) A 40-million-year lake record of Early Mesozoic orbital climatic forcing. Science, 234, 842-848.

Olsen, H. (1994) Orbital forcing on continental depositional systems-lacustrine and fluvial cyclicity in the Devonian of East Greenland. In: Orbital Forcing and Cyclic Sequences
(Eds P.L. de Boer and D.G. Smith), Spec. Publ. Int. Assoc. Sedimentol., 19, 429-438.

Ortí, F., Rosell, L., Fallick, A.E. and Utrilla, R. (1994) Yesosde Calatayud: aplicación del estudio de facies y geoquímica de sulfatos al conocimiento de un sistema evaporítico. Geogaceta, 15, 74-77.

Peláez-Campomanes, P., van der Meulen, A.J., Morales, J., Alonso-Zarza, A.M., Alvarez Sierra, M.A., Azanza, B., Calvo, J.P., Garcés, M., García Paredes, I., Hernandez, M., Nieto, M., Quiralte, V., Salesa, M., Sanchez, I. and Soria, D. (2000) The Aragonian-Vallesian boundary in the DarocaNombrevilla area (Zaragoza, Spain). Meeting: Environments and Ecosystem Dynamics of the Eurasian Neogene (EEDEN), Lyon, Abstracts, pp. 48-49.

Pierre, C., Ortlieb, L. and Person, A. (1984) Supratidal evaporitic dolomite at Ojo de Liebre lagoon: mineralogical and isotopic arguments for primary crystallization. J. Sed. Petrol., 54, 1049-1061.

Platt, N.H. (1989) Lacustrine carbonates and pedogenesis: sedimentology and origin of palustrine deposits from the Early Cretaceous Rupelo Formation, W. Cameros Basin, N. Spain. Sedimentology, 36, 665-684.

Platt, N.H. and Wright, V.P. (1991) Lacustrine carbonates: facies models, facies distributions and hydrocarbon aspects. In: Lacustrine Facies Analysis (Eds P. Anadón, L. Cabrera and K. Kelts), Spec. Publ. Int. Assoc. Sedimentol., 13, 57-74.

Platt, N.H. andWright, V.P. (1992)Palustrinecarbonates at the Florida Everglades: towards an exposure index for the freshwater environment? J. Sed. Petrol., 62, 1058-1071.

Reinhardt, L. and Ricken, W. (2000) The stratigraphic and geochemical record of Playa Cycles: monitoring a Pangean monsoon-like system (Triassic, Middle Keuper, S. Germany). Palaeogeogr. Palaeoclimatol. Palaeoecol., 61, 205-227.

Retallack, G.J. (1988) Field recognition of paleosols. In: Paleosols and Weathering Through Geologic Time (Eds J. Reinhardt and W.R. Sigles), Geol. Soc. Am. Spec. Paper, 216, 1-20.

Retallack, G.J. (1990) Soils of the Past. An Introduction to Paleopedology. Unwin Hyman, Boston, 520 pp.

Ripepe, M., Roberts, L.T. and Fischer, A.G. (1991) Enso and sunspot cycles in varved Eocene oil shales from image analysis. J. Sed. Petrol., 61, 1155-1163.

Rodríguez-Aranda, J.P. and Calvo, J.P. (1998) Trace fossils and rhizoliths as a tool for sedimentological and palaeoenvironmental analysis of ancient continental evaporite successions. Palaeogeogr. Palaeoclimatol. Palaeoecol., 140, 383-399.

Rosen, M.R. and Coshell, L. (1992) A new location of Holocene dolomite formation, Lake Hayward, Western Australia. Sedimentology, 39, 161-166.

Rosen, M.R., Miser, D.E., Starcher, M.A. and Warren, J.K. (1989) Formation of dolomite in the Coorong region, South Australia. Geochim. Cosmochim. Acta, 53, 661-669.

Rossi, C. and Cañaveras, J.C. (1999) Pseudospherulitic fibrous calcite in paleo-groundwater, unconformity-related diagenetic carbonates (Paleocene of the Áger Basin and Miocene of the Madrid Basin, Spain). J. Sed. Res., 69, 224238.

Rust, B.R. (1978) Depositional models for braided alluvium. In: Fluvial Sedimentology (Ed. A.D. Miall), Can. Soc. Petrol. Geol. Mem., 5, 605-625.

Rust, B.R. and Nanson, G.C. (1989) Bedload transport of mud as pedogenic aggregates in modern and ancient rivers. Sedimentology, 36, 291-306. 
Sanz, M.E., Alonso-Zarza, A.M. and Calvo, J.P. (1995) Carbonate pond deposits related to semi-arid alluvial systems: examples from the Tertiary Madrid Basin, Spain. Sedimentology, 42, 437-452.

Sanz-Rubio, E. (1999) Análisis de los Sistemas Deposicionales Carbonáticos y Evaporíticos del Neógeno de la Cuenca de Calatayud (Provincia de Zaragoza). PhD Thesis (unpublished), Universidad Complutense, Madrid, 579 pp.

Sanz-Rubio, E., Hoyos, M., Calvo, J.P. and Rouchy, J.M. (1999) Nodular anhydrite growth controlled by pedogenic structures in evaporite lake formations. Sed. Geol., 125, 195-203.

Sanz-Rubio, E., Sánchez-Moral, S., Cañaveras, J.C., Calvo, J.P. Rouchy, J.M. (2001) Calcitization of Mg-Ca carbonate and Ca sulphate deposits in a continental Tertiary basin (Calatayud Basin, NE Spain). Sed. Geol., 140, 123-142.

Seni, S.J. (1980) Sand-body Geometry and Depositional Systems, Ogalalla Formation, Texas. Report of Investigations 105. Bureau of Economic Geology, University of Texas at Austin, Austin, TX, 36 pp.

Sharma, T. and Clayton, R.N. (1965) Measurements of ${ }^{18} \mathrm{O} /{ }^{16} \mathrm{O}$ ratios of total oxygen and carbonates. Geochim. Cosmochim. Acta, 29, 1347-1353.

Simó n, J.L. (1990) Algunas reflexiones sobre los modelos tectónicos aplicados a la Cordillera Ibérica. Geogaceta, 8, 123-129.

Smoot, J.P. (1991) Sedimentary facies and depositional environments of early Mesozoic Newark Supergroup, eastern North America. Palaeogeogr. Palaeoclimatol. Palaeoecol., 84, 369-423.

Smoot, J.P. and Olsen, P.E. (1988) Massive mudstone in basin analysis and paleoclimatic interpretation of the Newark Supergroup. In: Triassic-Jurassic Rifting. Continental Breakup and the Origin of the Atlantic Ocean and Passive Margins (Ed. W. Manspeizer), Developments in Geotectonics 22, pp. 249-297. Elsevier, Amsterdam.

Spötl, C. and Wright, V.P. (1992) Groundwater dolocretes from the Upper Triassic of the Paris Basin, France: a case study of an arid, continental diagenetic facies. Sedimentology, 39, 1119-1136.

Steenbrink, J., van Vugt, N., Hilgen, F.J., Wijbrans, J.R. and Meulenkamp, J.E. (1999) Sedimentary cycles and volcanic ash beds in the Lower Pliocene lacustrine succession of Ptolemais (NW Greece): discrepancy between ${ }^{40} \mathrm{Ar} /{ }^{39} \mathrm{Ar}$ and astronomical ages. Palaeogeogr. Palaeoclimatol. Palaeoecol., 152, 283-303.

Talbot, M.R., Holm, K. and Williams, M.A.J. (1994) Sedimentation in low-gradient desert margin systems: A comparison of the Late Triassic of northwest Somerset (England) and the Late Quaternary of east-central Australia. In: Paleoclimate and Basin Evolution of Playa Systems (Ed. M.R. Rosen), Geol. Soc. Am. Spec. Paper, 289, 97-117.

Talbot, M.R. and Kelts, K. (1990) Paleolimnological signatures from carbon and oxygen isotopic ratios in organic carbon rich lacustrine sediments. In: Lacustrine Basin Exploration - Case Studies and Modern Analogs (Ed. B.J. Katz), AAPG Mem., 50, 99-112.
Turnbridge, I.P. (1984) Facies model for sandy ephemeral stream and clay playa complex, the Middle Devonian Trentishoe Formation of North Devon. Sedimentology, 31, 697-716.

Vandervoort, D.S. (1997) Stratigraphic response to saline lake-level fluctuations and the origin of cyclic nonmarine evaporite deposits: the Pleistocene Blanca Lila Formation, northwest Argentina. Geol. Soc. Am. Bull., 109, 210-224.

Van Houten, F. (1964) Cyclic lacustrine sedimentation, upper Triassic Lockatong formation, central New Jersey and adjacent Pennsylvania. Kansas Geol. Surv. Bull., 169, 497-532.

Van Vugt, N., Steenbrink, J., Langereis, C.G., Hilgen, F.J. and Meulenkamp, J.E. (1998) Magnetostratigraphy-based astronomical tuning of the early Pliocene lacustrine sediments of Ptolemais (NW Greece) and bed to bed correlation with the marine record. Earth Planet. Sci. Lett., 164, 535-551.

Vasconcelos, C. and McKenzie, J.A. (1997) Microbial mediation of modern dolomite precipitation and diagenesis under anoxic conditions (Lagoa Vermelha, Rio de Janeiro, Brazil). J. Sed. Res., 67, 378-390.

Von der Borch, C.C. and Lock, D. (1979) Geological significance of Coorong dolomites. Sedimentology, 26, 813-824.

Warren, J.K. (1983) Tepees, modern (southern Australia) and ancient (Permian - Texas and New Mexico) - a comparison. Sed. Geol., 34, 1-19.

Warren, J.K. (1990) Sedimentology and mineralogy of dolomitic Coorong lakes, South Australia. J. Sed. Petrol., 60, 843-858.

Wright, V.P. (1989) Paleosol recognition. In: Palaeosols in Siliciclastic Sequences (Eds J.R.L. Allen and V.P. Wright), pp. 1-25. PRIS Short Course Notes 001, Reading University.

Wright, V.P. (1990) Lacustrine carbonates. In: Carbonate Sedimentology (Eds M.E. Tucker and V.P. Wright), pp. 164190. Blackwell Science Publications, Oxford.

Wright, V.P. (1992) Paleopedology: stratigraphic relationships and empirical models. In: Weathering, Soils and Paleosols (Eds I.P. Martini, and W. Chesworth), pp. 475-499. Elsevier, Amsterdam.

Wright, D.T. (1999) The role of sulphate-reducing bacteria and cyanobacteria in dolomite formation in distal ephemeral lakes of the Coorong region, South Australia. Sed. Geol., 126, 147-157.

Wright, V.P. and Alonso-Zarza, A.M. (1990) Pedostratigraphic models for alluvial fan deposits: a tool for interpreting ancient sequences. J. Geol. Soc. London, 147, 8-10.

Wright, V.P. and Platt, N.H. (1995) Seasonal wetland carbonate sequences and dynamic catenas: a re-appraisal of palustrine limestones. Sed. Geol., 99, 65-71.

Wright, V.P. and Sandler, A. (1994) A hydrological model for the early diagenesis of Late Triassic alluvial sediments. J. Geol. Soc. London, 151, 897-900. 